\title{
The use of $\mathrm{Sr}$ isotope stratigraphy to date the Pleistocene sediments of the Norwegian continental shelf - a review
}

Keywords:

- Sr isotope stratigraphy

- Foraminiferal stratigraphy

- Dinoflagellate cyst stratigraphy

- Lithostratigraphy

- Seismic correlation

- Pleistocene

- North Sea

- Norwegian Sea shelf

Received:

17. February 2020

Accepted:

8. July 2020

Published online:

24. September 2020

\author{
Tor Eidvin ${ }^{1}$, Dag Ottesen², Karen Dybkjær ${ }^{3}$, Erik Skovbjerg Rasmussen ${ }^{3}$ \& Fridtjof \\ Riis $^{1}$ \\ ${ }^{1}$ Norwegian Petroleum Directorate (NPD), Professor Olav Hanssens vei 10, P. O. Box 600, N-4003 Stavanger, \\ Norway \\ ${ }^{2}$ Geological Survey of Norway (NGU), Leif Eirikssons vei 39, P. O. Box 6315 Torgarden, N-7491 Trondheim, \\ Norway \\ ${ }^{3}$ Geological Survey of Denmark and Greenland (GEUS), Øster Voldgade 10, DK-1350, Copenhagen K, \\ Denmark \\ E-mail corresponding author (Tor Eidvin): tor.eidvin@npd.no
}

Strontium ( $\mathrm{Sr}$ ) isotope data from cores and ditch-cutting samples from hydrocarbon wells from Pleistocene sediments from four areas on the Norwegian continental shelf have been compared with previously published biostratigraphic, lithostratigraphic, seismic and new micropaleontological and palynological data. The aim for this paper is also to provide a review of previous investigations of the use of $\mathrm{Sr}$ analysis on this margin, and to give a new assessment of some of the well samples by re-analysing these data and discuss the main limitations of the use of $\mathrm{Sr}$ isotopes to date Pleistocene sediments. It is important to obtain accurate dating of the Pleistocene sediments in order to constrain the age of glacial events, indicate the age of neotectonic periods and perform basin modelling. However, obtaining a good chronostratigraphy of the thick Pleistocene successions has proved to be very difficult. Since the sediments have been deposited during a relatively short time, there are few recorded fossil events as first and last appearance datums. $\mathrm{Sr}$ isotope stratigraphy based on analyses of calcareous mollusc and microfossil tests (foraminifera and Bolboforma) have proven an effective dating method particularly for Oligocene and Miocene sections on the Norwegian continental shelf. Dating Pliocene and especially Pleistocene sediments by means of $\mathrm{Sr}$ isotope stratigraphy has proved more difficult. The $\mathrm{Sr}$ isotope curves for the Pliocene to Pleistocene, in general, have lower gradients than the Oligocene and the Miocene parts, and small errors in the ${ }^{87} \mathrm{Sr} /{ }^{86} \mathrm{Sr}$ isotopic composition have a much larger impact when calculating ages from low-gradient parts of the $\mathrm{Sr}$ isotope seawater curves than from high-gradient parts. In addition, possible error sources comprise reworked fossil tests since a large portion of the marine Pleistocene deposits on the Norwegian continental shelf consists of redeposited older sediments originally deposited closer to the coast. These factors are probably the main reasons why the $\mathrm{Sr}$ isotope analyses of the investigated Pleistocene sections, with some exceptions, have not yielded very reliable ages.

(C) Copyright the authors. This work is licensed under a Creative Commons Attribution 4.0 International License.
Eidvin, T., Ottesen, D., Dybkjær, K., Rasmussen, E.S. \& Riis, F. 2020: The use of Sr isotope stratigraphy to date the Pleistocene sediments of the Norwegian continental shelf - a review. Norwegian Journal of Gelogy 100 , 202013. https://dx.doi.org/10.17850/njg100-3-1. 


\section{Introduction}

In the present paper, $\mathrm{Sr}$ isotope data from hydrocarbon wells from the Pleistocene succession in four areas on the Norwegian continental shelf have been compared with previously published biostratigraphic, lithostratigraphic and seismic data and with new micropaleontological and palynological data from one of the areas, the Visund Field. Additional aims are; 1 ) to provide a review of previous investigations of the use of Sr analysis on this margin; 2) to give a new evaluation of the well samples by re-analysing these data, and 3) to discuss the main limitations of the use of Sr isotopes to date Pleistocene sediments.

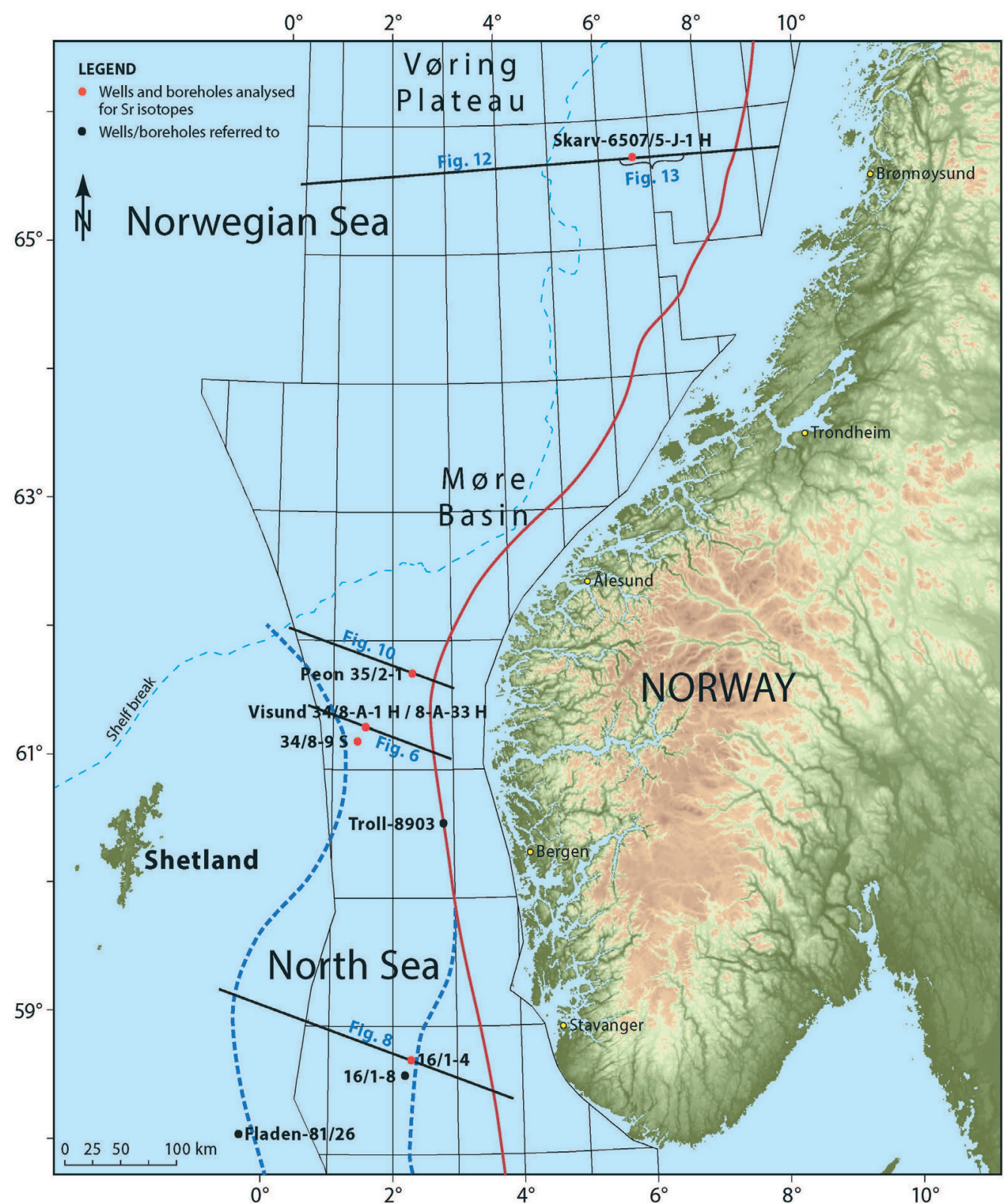

Figure 1. Map with the locations of analysed wells and boreholes (red dots), boreholes referred to in the text (black dots) and seismic lines (solid black lines). In the Norwegian Sea, the red solid line marks where the boundary between the Molo Formation and the lower Pleistocene prograding clinoforms subcrop towards younger Pleistocene sediments. In the southern part of the Norwegian Sea and in the North Sea, where the Molo Formation is not developed, the red solid line shows the termination/truncation of the base of the lower Pleistocene clinoforms towards the Upper Regional Unconformity (URU). Blue stippled lines are approximately $500 \mathrm{~m}$ depth contours of the base-Quaternary, showing the shape of the infilled North Sea Basin according to Ottesen et al. (2018). The topographic map of Norway is after Olesen et al. (2010) and the map is modified after Eidvin et al. (2013). 
In the northern North Sea, on the Norwegian Sea shelf and along the western margin of the Barents Sea, the Pleistocene succession (referred to as the Naust Formation) consists of prograding shelf sediments overlain by flat-lying sequences. The succession becomes thinner along the lower part of the continental slope. On the middle and inner Barents Sea shelf, the succession is relative thin and consists of till in some areas (Eidvin et al., in review). In the Møre Basin (Fig. 1) and in the area northeast of the Utgard High (Norwegian Sea shelf), the Naust Formation succession reaches a thickness of approximately 1500 m (Eidvin et al., 2000; Dahlgren et al., 2005; Rise et al., 2005; Ottesen et al., 2009, 2014; Eidvin et al. in review). Grounded ice sheets extended to the palaeo-shelf break on the Norwegian Sea shelf and in the northern North Sea during a number of successive glacial periods since the early Pleistocene (e.g., Rise et al., 2005; Ottesen et al., 2009, 2014, 2018; Batchelor et al., 2017; Montelli et al., 2017; Newton \& Huuse, 2017). The Naust Formation comprises mainly mud with outsized clasts and immature, poorly sorted sands. Apart from quartz and feldspars, the sand fraction contains a high proportion of granitic and metamorphic rock fragments. Pebbles and cobbles of such rock types are also common in many areas. In the western Barents Sea, pebbles of sedimentary rocks are also common. Shell debris occurs abundantly in parts of some sections (Eidvin \& Rundberg, 2007; Ottesen et al., 2009; Eidvin et al., 2013; in review). The prograding wedges of the Naust Formation include sub-horizontal layers mainly comprising till (including reworked strata), sloping strata dominated by reworked till (mainly by debris flows), and their distal part by glacimarine sediments from suspension (fine fractions) and icerafted detritus (IRD; coarse fraction). In some areas the oldest part of the Naust Formation consists of fine-grained contouritic deposits or glacimarine deposits interbedded with contouritic deposits.

Glacimarine sediments of the Vøring Plateau (Norwegian Sea) have been a subject of studies by Jansen \& Sjøholm (1991), Fronval \& Jansen (1996) and Eidvin et al. (1998). These studies demonstrated the presence of small amounts of fine-grained IRD as old as $12.6 \mathrm{Ma}$. The frequency of IRD increases somewhat during the period between 7.2 and $6.0 \mathrm{Ma}$ but remains relatively low between 6.0 and $2.75 \mathrm{Ma}$. A marked increase in the supply of IRD after about $2.75 \mathrm{Ma}$ reflects the expansion of the Scandinavian Ice Sheet. In ODP boreholes off the southeast coast of Greenland IRD has been recorded from sediments as old as 11 and $7 \mathrm{Ma}$, respectively, that indicate the onset of glaciations on southern Greenland in late Miocene (Larsen et al., 1994; Helland \& Holmes, 1997). It is likely that the IRD recorded from sediments older than $2.75 \mathrm{Ma}$ on the Vøring Plateau has been ice-rafted from the southern coast of Greenland (Fronval \& Jansen, 1996). The maximum age of the Naust Formation is assigned to be 2.75 Ma.

\section{Sampling Pleistocene sediments}

When drilling petroleum exploration and production wells, the oil companies sample the postEocene deposits with drill cuttings, except for the upper part of the Pleistocene. However, the postEocene deposits have been far less sampled than the pre-Oligocene sediments, which have been the main target for hydrocarbon exploration. The sampling programme is usually considerably less dense in these units than in the deeper sections, e.g., every ten metres compared to every three metres in reservoir sections. Just a small number of wells have been sampled with high-quality sidewall cores and short conventional cores. The conventional cores are used mainly for geotechnical investigations (Eidvin et al., 2013, in review). When drilling the Pleistocene parts of the wells, drill bits with large dimensions are used (usually 26" $(66 \mathrm{~cm})$ for the upper parts of successions and $171 / 2^{\prime \prime}(44.5 \mathrm{~cm})$ for the lower parts). The $26^{\prime \prime}$ parts of the boreholes are lined with 20" casing and the 171 / 2" parts are lined with 13 $3 / 8$ " casing. Before the casings are put in place the boreholes are open, in other words exposed to the rotating drill strings and to circulating drill mud. Most likely, the unconsolidated sediments are continuously dislodged throughout the drilling of the sections, and some will be incorporated into the drill-cutting samples. Only sampling in the form of sidewall cores and conventional cores can prevent incorporation of a significant amount of caved material in the Pleistocene samples, but, as mentioned above, only a small number of wells have been sampled in such a manner (Eidvin et al., in review). Fortunately, we were able to obtain sidewall cores or conventional cores from the wells in three of the four areas we have investigated in the present study. The investigated core-, sidewall core- and ditchcutting samples are covering most of the Pleistocene. If not stated otherwise, all depths in wells are expressed as metres below the rotary kelly bushing on the rig floor (mRKB). 


\section{Dating Pleistocene sediments}

It is very important to obtain accurate datings of the Pleistocene sediments in order to, among other things, constrain the age of the glacial events, indicate the age of neotectonic periods and perform basin modelling. However, obtaining a good chronstratigraphy of the thick Pleistocene successions has proved to bevery difficult. Since these sediments have been deposited over a relativelyshort time (c. the last 2.6 million years), there are few recorded micro-fossil events as first and last appearance datums (FADs and LADs). Sr isotope stratigraphy based on analyses of calcareous fossil tests has proven an effective dating method particularly for Oligocene and Miocene sections on the Norwegian continental shelf (Eidvin \& Rundberg, 2001, 2007; Eidvin et al., 2007; Eidvin et al., 2013). Dating Pliocene and especially Pleistocene sediments by means of Sr isotope stratigraphy has proved more difficult. The Sr isotope curves of Howarth \& McArthur $(1997,2004)$ for the Pliocene and Pleistocene have in general lower gradients than the Oligocene and Miocene parts (Fig. 2). Small errors in the ${ }^{87} \mathrm{Sr} /{ }^{86} \mathrm{Sr}$ isotopic composition due to possible minor impurities in the calcareous tests, re-crystallisation of the tests, errors introduced during sample preparation and the mass spectroscopy analysis process, etc., have a much larger impact when calculating ages from low-gradient parts of the $\mathrm{Sr}$ isotope curves than from high-gradient parts (Eidvin et al., 2014). ${ }^{87} \mathrm{Sr} /{ }^{86} \mathrm{Sr}$ isotopic compositions which give ages between 4.6 and $2.75 \mathrm{Ma}$ (latest early to late Pliocene) plot on the part of the Pliocene to Pleistocene curve which has the lowest gradient. The part which gives ages between 3.2 and $2.75 \mathrm{Ma}$ is almost completely flat. The parts of the curve for the Pleistocene which give ages of 2.75 to $1.6 \mathrm{Ma}$ and $1.05 \mathrm{Ma}$ to recent are somewhat steeper, and the part which gives ages between 1.6 and $1.05 \mathrm{Ma}$ is the steepest part of the Sr isotope curve for the Pleistocene and consequently, theoretically, should provide the most reliable Pleistocene ages (Fig. 2).

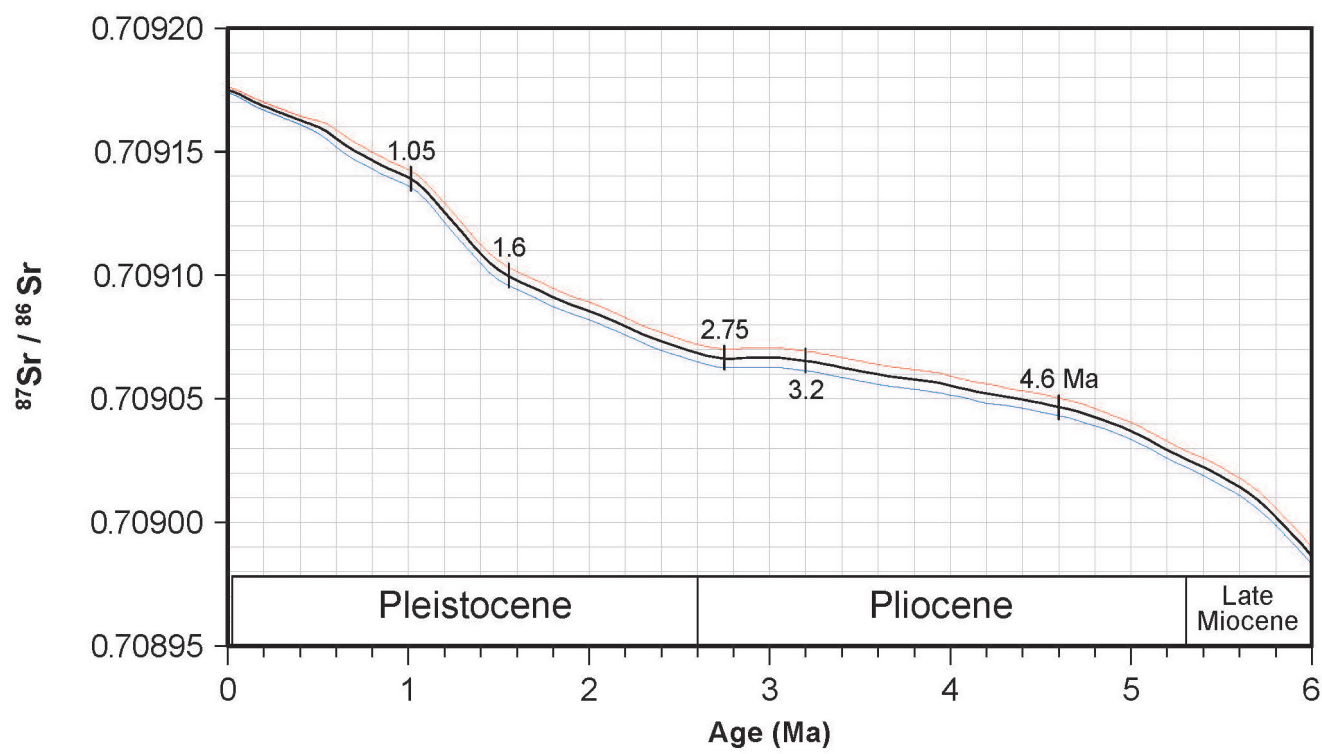

Figure 2. Curve showing Sr isotope ratio evolution of seawater from $6 \mathrm{Ma}$ to recent based on the look-up table of Howarth \& McArthur (1997), which is based on the time-scale of Berggren et al. (1995) with the Pliocene/Pleistocene boundary at $1.85 \mathrm{Ma}$. However, we have used a Pliocene/Pleistocene boundary at $2.588 \mathrm{Ma}$ according to the new time-scale of Cohen et al. (2013). Points on the curve where the slope changes are marked.

Another problem when dating Pleistocene sediments using Sr isotopes is that reworked mollusc and microfossil tests probably are very common in the sediments since a large portion of the marine Pleistocene deposits on the Norwegian continental shelf and slope are reworked from older sediments originally deposited closer to the coast. If the samples analysed for Sr-isotopes contain reworked tests, the dates represent the maximum age of the deposits.

As mentioned above, the ${ }^{87} \mathrm{Sr} /{ }^{86} \mathrm{Sr}$ ratios were converted to age estimates using the SIS look-up table of Howarth \& McArthur (1997; 2004; Tables 1-3 and 7-9). The look-up table of Howarth \& McArthur (1997) is based on the time-scale of Berggren et al. (1995) and the look-up table of Howarth \& McArthur (2004) is based on the time-scale of Gradstein et al. (2004). There is currently no SIS look-up table that is based 
on the new time-scale of Cohen et al. (2013). However, the absolute ages for the time-scales of Berggren et al. (1995), Gradstein et al. (2004) and Cohen et al. (2013) do not deviate very much for the Cenozoic. The most important difference is that in Cohen et al. (2013), the base Pleistocene is moved from 1.85 to $2.588 \mathrm{Ma}$. In the present paper we follow Cohen et al. (2013) and use 2.588 Ma as the age of the base of the Pleistocene (see Fig. 2).

\section{Correlation with seismic profiles}

We present four regional seismic profiles, one from each of the investigated areas to illustrate the stratigraphic context of the samples that have been analysed for $\mathrm{Sr}$ ages. In addition, we present a shorter, more detailed profile in the 6507/5-J-1 H area. All the samples are taken from the Pleistocene Naust Formation except for the two lowermost samples from well 16/1-4, which have been sampled in the Utsira Formation. The samples taken from the Naust Formation are all from the older Naust units, except from those from well 35/2-1. This well penetrates the Peon gas reservoir, which is located in flat-lying sandy sediments above the Upper Regional Unconformity (URU), forming the base of the Norwegian Channel in this area.

Table 1. Sr isotope data from well 34/8-9 S. Samples analysed in 1999-2001 by UiB are modified from Eidvin \& Rundberg (2001). The Sr ratios are corrected to NIST $987=0.710248$. Numerical ages derived from the SIS look-up tables of Howarth \& McArthur (1997, 2004). NIST - National Institute for Standard and Technology. UiB - University of Bergen.

\begin{tabular}{|c|c|c|c|c|c|c|}
\hline $\begin{array}{l}\text { Litho. } \\
\text { Unit }\end{array}$ & $\begin{array}{l}\text { Sample } \\
\text { depth } \\
\text { (core) }\end{array}$ & $\begin{array}{l}\text { Corrected } \\
{ }^{87 / 86} \mathrm{Sr}\end{array}$ & $2 \mathrm{~S}$ error & $\begin{array}{l}\text { Age (Ma; H\&M, } \\
1997 / 2004 \\
\text { mean value) }\end{array}$ & Comments & Analysed fossils \\
\hline Naust Fm & $1109.68 \mathrm{~m}$ & 0.709086 & 0.000011 & $1.98,1.97$ & $\begin{array}{l}\text { Analysed in 1999- } \\
2001 \text { by UiB }\end{array}$ & 50 tests of $N$. affine, $C$. teretis, $C$. scaldisiensis \\
\hline Naust Fm & $1109.68 \mathrm{~m}$ & 0.709044 & 0.000008 & $4.74,4.70$ & $\begin{array}{l}\text { Analysed in } 2016 \\
\text { by UiB }\end{array}$ & One mollusc fragment \\
\hline Naust Fm & $1109.68 \mathrm{~m}$ & 0.709060 & 0.000009 & $3.59,3.14$ & $\begin{array}{l}\text { Analysed in } 2016 \\
\text { by UiB }\end{array}$ & $\begin{array}{l}30 \text { tests of } N \text {. affine, C. teretis, } C \text {. lobatulus, G. } \\
\text { bulloides, A. fluens, Fissurina sp. }\end{array}$ \\
\hline Naust Fm & $1109.68 \mathrm{~m}$ & 0.709041 & 0.000016 & $4.86,4.82$ & $\begin{array}{l}\text { Analysed in } 2016 \\
\text { by UiB }\end{array}$ & $\begin{array}{l}30 \text { tests of } N \text {. affine, } C \text {. teretis, } \\
\text { G. bulloides, } A \text {. fluens, } B \text {. marginata }\end{array}$ \\
\hline Naust Fm & $1110.52 \mathrm{~m}$ & 0.709013 & 0.000013 & $5.63,5.65$ & $\begin{array}{l}\text { Analysed in 1999- } \\
2001 \text { by UiB }\end{array}$ & $\begin{array}{l}47 \text { tests av } C . \text { grossus, } C . \text { scaldisiensis, } E \text {. } \\
\text { groenlandicum }\end{array}$ \\
\hline Naust Fm & $1110.52 \mathrm{~m}$ & 0.709038 & 0.000009 & $4.97,4.93$ & $\begin{array}{l}\text { Analysed in } 2016 \\
\text { by UiB }\end{array}$ & $\begin{array}{l}30 \text { tests of Guttulina sp., E. excavatum, E. } \\
\text { albiumbilicatum, E. groenlandicum, C. teretis, C. } \\
\text { lobatulus }\end{array}$ \\
\hline Naust Fm & $1110.52 \mathrm{~m}$ & 0.708975 & 0.000009 & $6.14,6.35$ & $\begin{array}{l}\text { Analysed in } 2016 \\
\text { by UiB }\end{array}$ & Two mollusc fragments \\
\hline Naust Fm & $1110.52 \mathrm{~m}$ & 0.709036 & 0.000009 & $5.03,4.99$ & $\begin{array}{l}\text { Analysed in } 2016 \\
\text { by UiB }\end{array}$ & $\begin{array}{l}30 \text { tests of Fissurina sp., C. teretis, N. atlantica } \\
\text { (sin.), G. bulloides, N. affine, E. albiumbilicatum }\end{array}$ \\
\hline Naust Fm & $1111.74 \mathrm{~m}$ & 0.709007 & 0.000013 & $5.73,5.77$ & $\begin{array}{l}\text { Analysed in 1999- } \\
2001 \text { by UiB }\end{array}$ & $\begin{array}{l}40 \text { tests of } N \text {. affine, C. teretis, G. bulloides, } N \text {. } \\
\text { atlantica (sin.), G. bulloides }\end{array}$ \\
\hline Naust Fm & $1111.74 \mathrm{~m}$ & 0.709008 & 0.000009 & $5.72,5.75$ & $\begin{array}{l}\text { Analysed in } 2016 \\
\text { by UiB }\end{array}$ & $\begin{array}{l}28 \text { tests of L. lammersi, A. fluens, C. teretis, G. } \\
\text { bulloides, N. atlantica (sin.) }\end{array}$ \\
\hline Naust Fm & $1112.63 \mathrm{~m}$ & 0.709054 & 0.000012 & $4.10,3.88$ & $\begin{array}{l}\text { Analysed in 1999- } \\
2001 \text { by UiB }\end{array}$ & $\begin{array}{l}45 \text { tests of } C . \text { grossus, C. scaldisiensis, } E \text {. } \\
\text { groenlandicum }\end{array}$ \\
\hline Naust Fm & $1112.63 \mathrm{~m}$ & 0.708978 & 0.000010 & $6.10,6.28$ & $\begin{array}{l}\text { Analysed in 1999- } \\
2001 \text { by UiB }\end{array}$ & Four mollusc fragments \\
\hline Naust Fm & $1112.63 \mathrm{~m}$ & 0.709014 & 0.000008 & $5.61,5.63$ & $\begin{array}{l}\text { Analysed in } 2016 \\
\text { by UiB }\end{array}$ & $\begin{array}{l}30 \text { tests of } C \text {. lobatulus, Fissurina sp., } \\
\text { E. groenlandicum, E. albiumbilicatum, C. teretis }\end{array}$ \\
\hline Naust Fm & $1112.63 \mathrm{~m}$ & 0.709029 & 0.000009 & $5.21,5.22$ & $\begin{array}{l}\text { Analysed in } 2016 \\
\text { by UiB }\end{array}$ & $\begin{array}{l}30 \text { tests of } C \text {. teretis, E. groenlandicum, } \\
\text { E. albiumbilicatum, Fissurina sp. }\end{array}$ \\
\hline Naust Fm & $1112.63 \mathrm{~m}$ & 0.708998 & 0.000007 & $5.85,5.93$ & $\begin{array}{l}\text { Analysed in } 2016 \\
\text { by UiB }\end{array}$ & One mollusc fragments \\
\hline
\end{tabular}


Table 2. Sr isotope data from well 34/8-A-1 H. Samples analysed in 1999-2001 by UiB and 1999-2000 by IFE are modified from Eidvin \& Rundberg (2001). The Sr ratios are corrected to NIST $987=0.710248$. Numerical ages derived from the SIS look-up tables of Howarth \& McArthur (1997, 2004). NIST - National Institute for Standard and Technology. UiB - University of Bergen, IFE - Institutt for Energiteknikk, Keller.

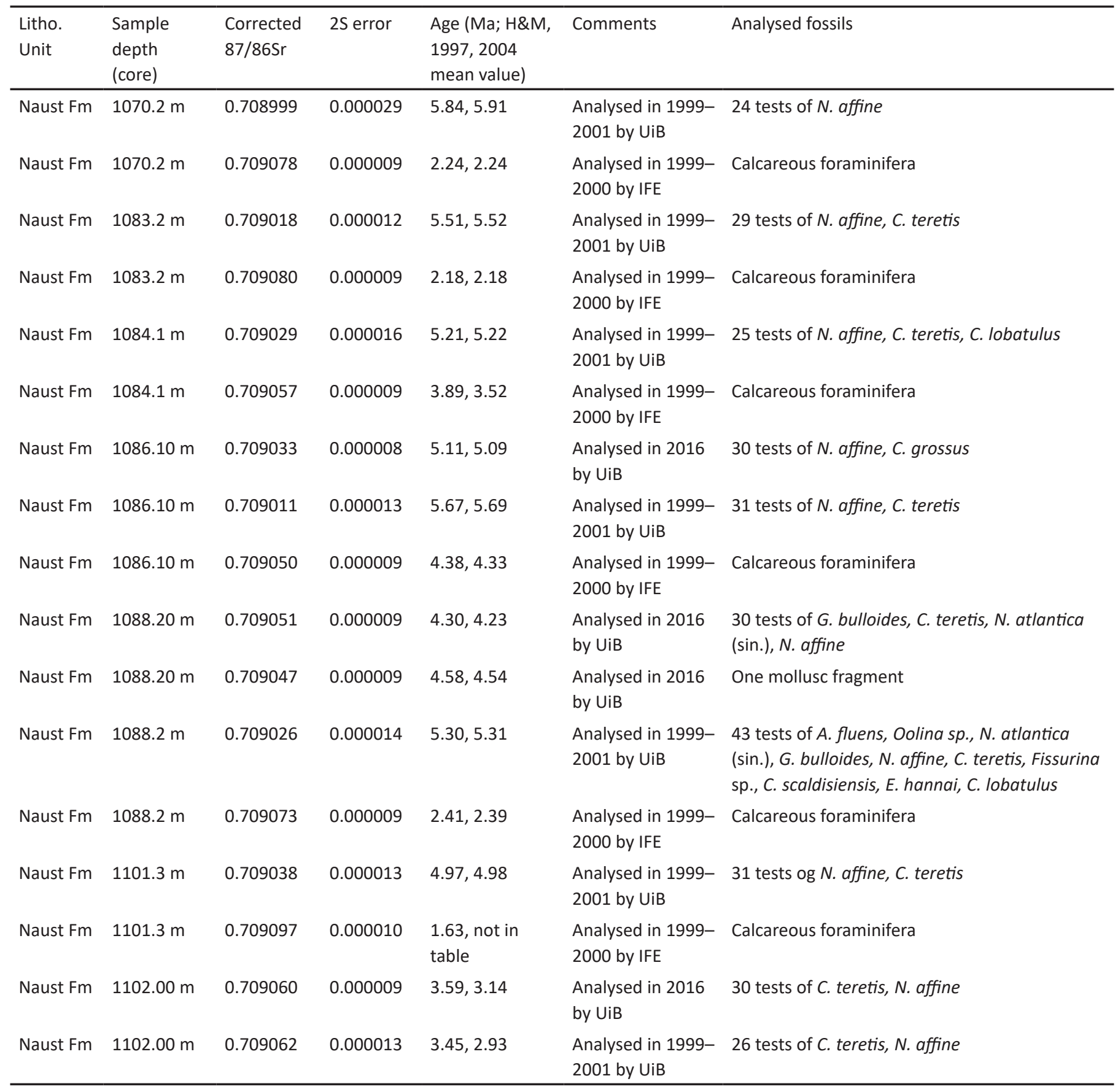


Table 3. Sr isotope data from well 34/8-A-33 H. The samples were analysed at the University of Bergen. Sr ratios were corrected to NIST 987 = 0.710248. Numerical ages derived from the SIS look-up tables of Howarth \& McArthur (1997, 2004). NIST - National Institute for Standard and Technology.

\begin{tabular}{|c|c|c|c|c|c|c|}
\hline Litho. Unit & $\begin{array}{l}\text { Sample } \\
\text { depth } \\
\text { (core) }\end{array}$ & $\begin{array}{l}\text { Corrected } \\
{ }^{87 / 86} \mathrm{Sr}\end{array}$ & $2 \mathrm{~S}$ error & $\begin{array}{l}\text { Age (Ma; H\&M, } \\
\text { 1997, } 2004 \\
\text { mean values) }\end{array}$ & Comments & Analysed fossils \\
\hline Naust Fm & $1125.8 \mathrm{~m}$ & 0.709064 & 0.000009 & $3.31,2.78$ & $\begin{array}{l}\text { Analysed in } 2016 \\
\text { by UiB }\end{array}$ & 30 tests of $G$. bulloides, N. alantica (sin.) \\
\hline Naust Fm & $1125.8 \mathrm{~m}$ & 0.709042 & 0.000008 & $4.82,4.78$ & $\begin{array}{l}\text { Analysed in } 2016 \\
\text { by UiB }\end{array}$ & 30 tests of $C$. teretis, $C$. lobatulus, $N$. affine \\
\hline Naust Fm & $1125.8 \mathrm{~m}$ & 0.709051 & 0.000009 & $4.30,4.23$ & $\begin{array}{l}\text { Analysed in } 2016 \\
\text { by UiB }\end{array}$ & Two mollusc fragments \\
\hline Naust Fm & $1128.3 \mathrm{~m}$ & 0.709069 & 0.000008 & $2.57,2.54$ & $\begin{array}{l}\text { Analysed in } 2016 \\
\text { by UiB }\end{array}$ & 25 tests of $C$. lobatulus \\
\hline Naust Fm & $1128.3 \mathrm{~m}$ & 0.709065 & 0.000008 & $3.23,2.78$ & $\begin{array}{l}\text { Analysed in } 2016 \\
\text { by UiB }\end{array}$ & 30 tests of $N$. affine \\
\hline Naust Fm & $1128.3 \mathrm{~m}$ & 0.709007 & 0.000009 & $5.73,5.57$ & $\begin{array}{l}\text { Analysed in } 2016 \\
\text { by UiB }\end{array}$ & One mollusc fragment \\
\hline Naust Fm & $1129.7 \mathrm{~m}$ & 0.709090 & 0.000012 & $1.84,1.83$ & $\begin{array}{l}\text { Analysed in 2012- } \\
2013 \text { by UiB }\end{array}$ & Approximately 100 tests of E. pygmes \\
\hline Naust Fm & $1129.7 \mathrm{~m}$ & 0.709070 & 0.000011 & $2.52,2.50$ & $\begin{array}{l}\text { Analysed in 2012- } \\
2013 \text { by UiB }\end{array}$ & Approximately 110 tests of E. pygmes \\
\hline Naust Fm & $1141.8 \mathrm{~m}$ & 0.709023 & 0.000009 & $5.38,5.41$ & $\begin{array}{l}\text { Analysed in } 2016 \\
\text { by UiB }\end{array}$ & $\begin{array}{l}30 \text { tests of } \text { C. teretis, N. affine. A. angulosa, } \\
\text { C. scaldisiensis, C. lobatulus, G. bulloides, } \\
\text { N. atlantica (sin.), B. marginata }\end{array}$ \\
\hline Naust Fm & $1141.8 \mathrm{~m}$ & 0.709034 & 0.000009 & $5.08,5.06$ & $\begin{array}{l}\text { Analysed in } 2016 \\
\text { by UiB }\end{array}$ & $\begin{array}{l}30 \text { tests of } C \text {. teretis, N. affine, A. angulosa, } \\
\text { B. marginata, Fissurina sp., N. atlantica } \\
\text { (sin.), G. bulloides }\end{array}$ \\
\hline Naust Fm & $1141.8 \mathrm{~m}$ & 0.709054 & 0.000008 & $4.10,3.88$ & $\begin{array}{l}\text { Analysed in } 2016 \\
\text { by UiB }\end{array}$ & 13 large tests of $E$. variabilis \\
\hline
\end{tabular}

\section{Results}

\section{Area 1; wells 34/8-9 S, 34/8-A-1 $\mathrm{H}$ and 34/8-A-33 $\mathrm{H}$ from the Visund Field (Tampen, northern North Sea)}

In the exploration well $34 / 8-9 \mathrm{~S}\left(61^{\circ} 18^{\prime} 50.53^{\prime \prime} \mathrm{N}, 02^{\circ} 23^{\prime} 17.89^{\prime \prime} \mathrm{E}\right.$; Fig. 1) and the production well $34 / 8-\mathrm{A}-1 \mathrm{H}\left(61^{\circ} 22^{\prime} 12.57^{\prime \prime} \mathrm{N}, 02^{\circ} 27^{\prime} 35.13^{\prime \prime} \mathrm{E}\right.$; Fig. 1), Eidvin \& Rundberg (2001) have investigated short cored sections in the basal part of the Naust Formation for micropaleontology, lithology and Sr isotope ratios. In well 34/8-9S, samples at $1109.88,1110.52,1111.74$ and $1112.63 \mathrm{~m}$ were investigated (Table 1) and in well34/8-A-1 H samples at 1070.2,1083.2,1084.1,1086.1,1088.2,1101.3 and $1102 \mathrm{~m}$ were investigated (Table 2). For the present study, seven samples (1125.8, 1128.3, 1129.7, 1131.7, 1133.7, 1134.5 , and $1141.8 \mathrm{~m}$ ) from a cored section in the same part of the Naust Formation were investigated in the production well $34 / 8-\mathrm{A}-33 \mathrm{H}\left(61^{\circ} 22^{\prime} 13.5^{\prime \prime} \mathrm{N}, 02^{\circ} 27^{\prime} 34.63^{\prime \prime} \mathrm{E}\right.$; Fig. 1) for micropaleontology and lithology. The samples at 1125.8, 1128.3, 1129.7 and $1141.8 \mathrm{~m}$ were also investigated for $\mathrm{Sr}$ isotope ratios (Table 3). Also, for the present study the sediments in all the cores have been described and the sedimentary facies were interpreted. Finally, the samples at 1083.2 and 1084.1 $\mathrm{m}$ from well 34/8-A-1 H (Table 4), the samples at 1124.8 and $1125.8 \mathrm{~m}$ from well 34/8-A-33 H (Table 5) and the samples at 1109.7 and $1112.63 \mathrm{~m}$ from well 34/8-9 S (Table 6) were analysed for palynomorphs. 
$1084.10 \mathrm{~m}^{*}$

Lower-Middle Miocene

Oligocene - Miocene

Oligocene

Eocene - Oligocene

Lower - lowermost Middle Eocene

Lowermost Eocene

Paleocene

Cretaceous - Paleocene

Jurassic - L. Cretaceous

Jurassic

Carboniferous semimuris
$1083.20 \mathrm{~m}^{* *}$

Cousteaudinium aubryae

Apteodinium tectatum

Apteodinium australiense

Chiropteridium lobospinosum

Chiropteridium lobospinosum Wetzeliella gochtii

Thalassiphora fenestrata Wetzeliella sp.

Thalassiphora fenestrata Wetzeliella sp.

\section{Eatonicysta ursulae}

Apectodinium augustum

Palaeoperidinium pyrophorum Cerodinium striata

Alterbia sp.

Cicatricosisporites sp.

Gleicheniidites senonicus

Chasmatosporites apertus Lycopodiumsporites

\section{Corollina torosus} Glossodinium dimorphum Gonyaulacysta sp. Senoniasphaera jurassica

Densosporites sp.

*In addition, several long-ranging taxa were recorded in the sample at $1084.10 \mathrm{~m}$ including Cleistosphaeridium placacanthum, Cordosphaeridium cantharellus, Homotryblium plectilum, H. tenuispinosum and Reticulosphaera actinocoronata. All these taxa appear in the Eocene-Oligocene and ranges into the Miocene - the latter species even into the lower Pliocene.

**In addition, the taxa Caligodinium amiculum, Cleistosphaeridium placacanthum, Deflandrea phosphoritica and Homotryblium plectilum were recorded in the sample at $1083.20 \mathrm{~m}$. All these taxa are long-ranging, from the Eocene-Miocene.

The Carboniferous spore genus Densosporites was recorded in both samples. These spores may, however, be the result of recycling as reworked Carboniferous spores are well-known from Jurassic deposits. 
Table 5. Reworked palynomorphs in well 34/8-A-33 H.

\begin{tabular}{|c|c|c|}
\hline & $1125.80 \mathrm{~m}^{*}$ & $1124.80 \mathrm{~m}$ \\
\hline Miocene & Apteodinium tectatum & $\begin{array}{l}\text { Labyrinthodinium truncatum } \\
\text { Palaeocystodinium minor }\end{array}$ \\
\hline Oligocene-Miocene & Apteodinium australiense & \\
\hline Oligocene & & Distatodinium biffii \\
\hline Eocene-Oligocene & Areoligera sp. & Wetzeliella sp. \\
\hline Lowermost Eocene & & Apectodinium augustum \\
\hline Paleocene & & Palaeoperidinium pyrophorum \\
\hline Cretaceous - Paleocene & & Alterbia sp. \\
\hline Jurassic - Lower Cretaceous & & $\begin{array}{l}\text { Cicatricosisporites sp. } \\
\text { Gleicheniidites spp. } \\
\text { Scriniodinium campanula } \\
\text { Sirmiodinium grossii }\end{array}$ \\
\hline Jurassic & $\begin{array}{l}\text { Callialasporites dampieri } \\
\text { Chasmatosporites apertus } \\
\text { Lycopodiumsporites } \\
\text { semimuris L. } \\
\text { austroclavatidites }\end{array}$ & $\begin{array}{l}\text { Baculatisporites spp. } \\
\text { Callialasporites dampieri } \\
\text { Cerebropollenites macroverrucosus } \\
\text { Chasmatosporites spp. } \\
\text { Corollina torosus } \\
\text { Glossodinium dimorphum } \\
\text { Klukisporites sp. } \\
\text { Lycopodiumsporites } \\
\text { austroclavatidites } \\
\text { L. clavatoides } \\
\text { L. semimuris } \\
\text { Quadraeculina anellaeformis } \\
\text { Sestrosporites pseudoalveolatus }\end{array}$ \\
\hline Upper Permian - ?Lower & & Lueckisporites virkkiae \\
\hline Triassic & & Vittatina sp. \\
\hline Carboniferous & Densosporites sp. & Densosporites sp. \\
\hline
\end{tabular}

*In addition, the species Homotryblium plectilum was recorded in the sample from $1125.80 \mathrm{~m}$. This species is long-ranging, from deposits of Eocene-Miocene in age.

As in well 34/8-A-1, the Carboniferous spore genus Densosporites was recorded in both samples from this well. Also here, these spores may be the result of recycling as reworked Carboniferous spores are well-known from Jurassic deposits. 
Table 6. Reworked palynomorphs in well 34/8-9 S.

\begin{tabular}{|c|c|c|}
\hline & $1112.53 \mathrm{~m}^{*}$ & $1109.70 \mathrm{~m} * *$ \\
\hline Miocene & $\begin{array}{l}\text { Apteodinium tectatum } \\
\text { Cerebrocysta satchelliae } \\
\text { Cousteaudinium aubryae } \\
\text { Exochosphaeridium insigne } \\
\text { Hystrichosphaeridium obscura } \\
\text { Labyrinthodinium truncatum } \\
\text { Palaeocystodinium miocaenicum }\end{array}$ & Apteodinium tectatum \\
\hline Oligocene-Miocene & Apteodinium australiense & \\
\hline Oligocene & $\begin{array}{l}\text { Spiniferites manumii } \\
\text { Wetzeliella gochtii }\end{array}$ & Spiniferites manumii \\
\hline Eocene-Oligocene & $\begin{array}{l}\text { Areoligera semicirculata } \\
\text { Thalassiphora fenestrate } \\
\text { Wetzeliella spp }\end{array}$ & Wetzeliella spp. \\
\hline Lowermost Eocene & Apectodinium quinquelatum & \\
\hline Paleocene - Eocene & Deflandrea oebisfeldensis & \\
\hline Paleocene & Palaeoperidinium pyrophorum & Spinidinium densispinatum \\
\hline Lower Cretaceous & & Oligosphaeridium complex \\
\hline Jurassic - Lower Cretaceous & Sirmiodinium grossii & $\begin{array}{l}\text { Cicatricosisporites sp. } \\
\text { Systematophora daveyi }\end{array}$ \\
\hline Jurassic & $\begin{array}{l}\text { Baculatisporites spp. } \\
\text { Callialasporites dampieri } \\
\text { Cerebropollenites thiergartii } \\
\text { Chasmatosporites apertus } \\
\text { C. hians } \\
\text { Corollina torosus } \\
\text { Lycopodiumsporites austroclavatidites } \\
\text { Quadraeculina anellaeformis }\end{array}$ & $\begin{array}{l}\text { Baculatisporites spp. } \\
\text { Cerebropollenites } \\
\text { macroverrucosus } \\
\text { Chasmatosporites hians } \\
\text { Corollina torosus } \\
\text { Nannoceratopsis gracilis } \\
\text { Uvaesporites argenteaeformis }\end{array}$ \\
\hline
\end{tabular}

*In addition, the species Chiropteridium spp., Cleistosphaeridium placacanthum, Cordosphaeridium cantharellus, Homotryblium plectilum and Palaeocystodinium golzowense were recorded in the sample from $1112.53 \mathrm{~m}$. These species are long-ranging, from deposits of Eocene/Oligocene to Miocene in age.

**In addition, the species Cleistosphaeridium placacanthum was recorded in the sample from $1109.70 \mathrm{~m}$. This species is long-ranging, from deposits of Eocene to Miocene in age. 


\section{Lithology}

The cored sections in the wells 34/8-9 S, 34/8-A-1 H and 34/8-A-33 $\mathrm{H}$ are composed of typical contourite deposits (Fig. 3). The sediments consist mainly of alternating silty mudstones and fine-grained sandstones. The sandstones show a grading pattern including both coarsening-upwards and fining-upwards trends (Fig. 3). The sediment is completely bioturbated. At some levels there are concentrations of foraminifera which are sorted by size that clearly indicate deposition from currents. Icerafted pebbles and cobbles of mainly metamorphic rocks are common. Two large ice-rafted clasts of

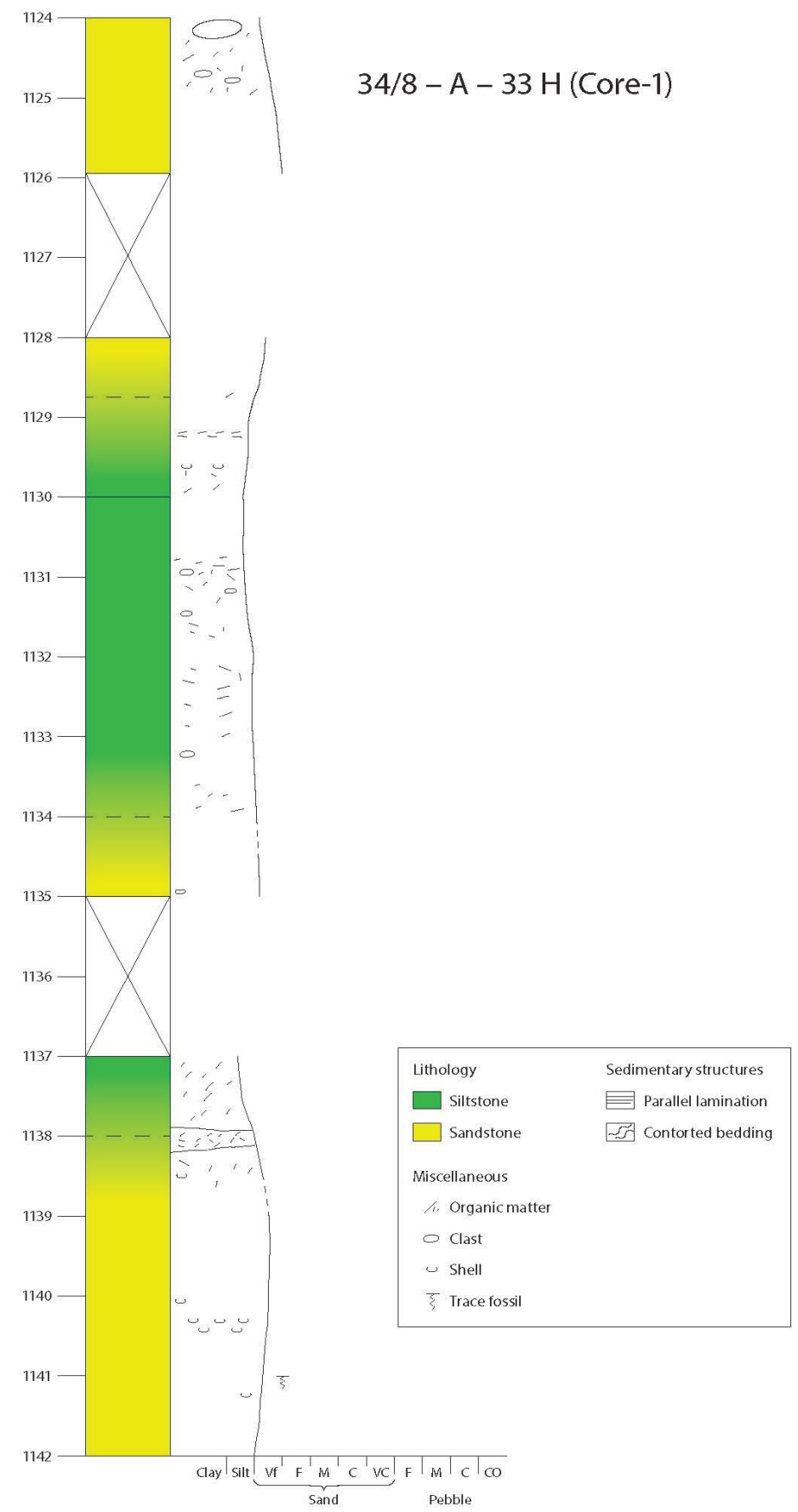

Figure 3. Sediment section of 34/8-A-33 H (core 1). Note the coarsening-and fining-upward trends of the section which is a characteristic feature of contourite deposits. The missing sections are probably sand-rich sections. 
metamorphic rocks (quartzite and gneiss) were recorded from the upper part of the core in well 34/8-A-33 H (1124 m; Fig. 4). A number of smaller cobbles and pebbles of crystalline rocks are visible in the other cores (see also Eidvin \& Rundberg (2001) and Ottesen et al. (2009)). The main part of the cored section (Fig. 3) is showing a gradual increase in grain size followed by decreasing grain size upwards, which is typical for contourites (Gonthier et al., 1984; Stow \& Faugeres, 2008). The changes in grain size indicate waxing and waning of bottom currents. In well 34/8-A-33 H core-1 (Fig. 3), two separate sections (two metres each) are missing at 1126-1128 m and1135-1137m, respectively. The missing intervals are between a coarsening-upwards and a fining-upwards succession. It is most likely that the missing sections are sand-rich intervals and consequently have a low core recovery. Such parts may thus represent the most coarse-grained portion of a contourite (facies C3, e.g., Rodriguez-Tovar \& Hernandez-Molina, 2018) and truly show the negative - positive gradation of the succession that is characteristic for contourites. The occurrence of well-sorted foraminifera clearly indicates current activity in the area and thus strongly supports the interpretation of contourite deposits. The identified trace fossils Planolites and Thalassinoides are also typical for contourites (Rodriguez-Tovar \& Hernandez-Molina, 2018). Core photos of the Visund cores are available at the NPD fact-pages (npd.no/facts).

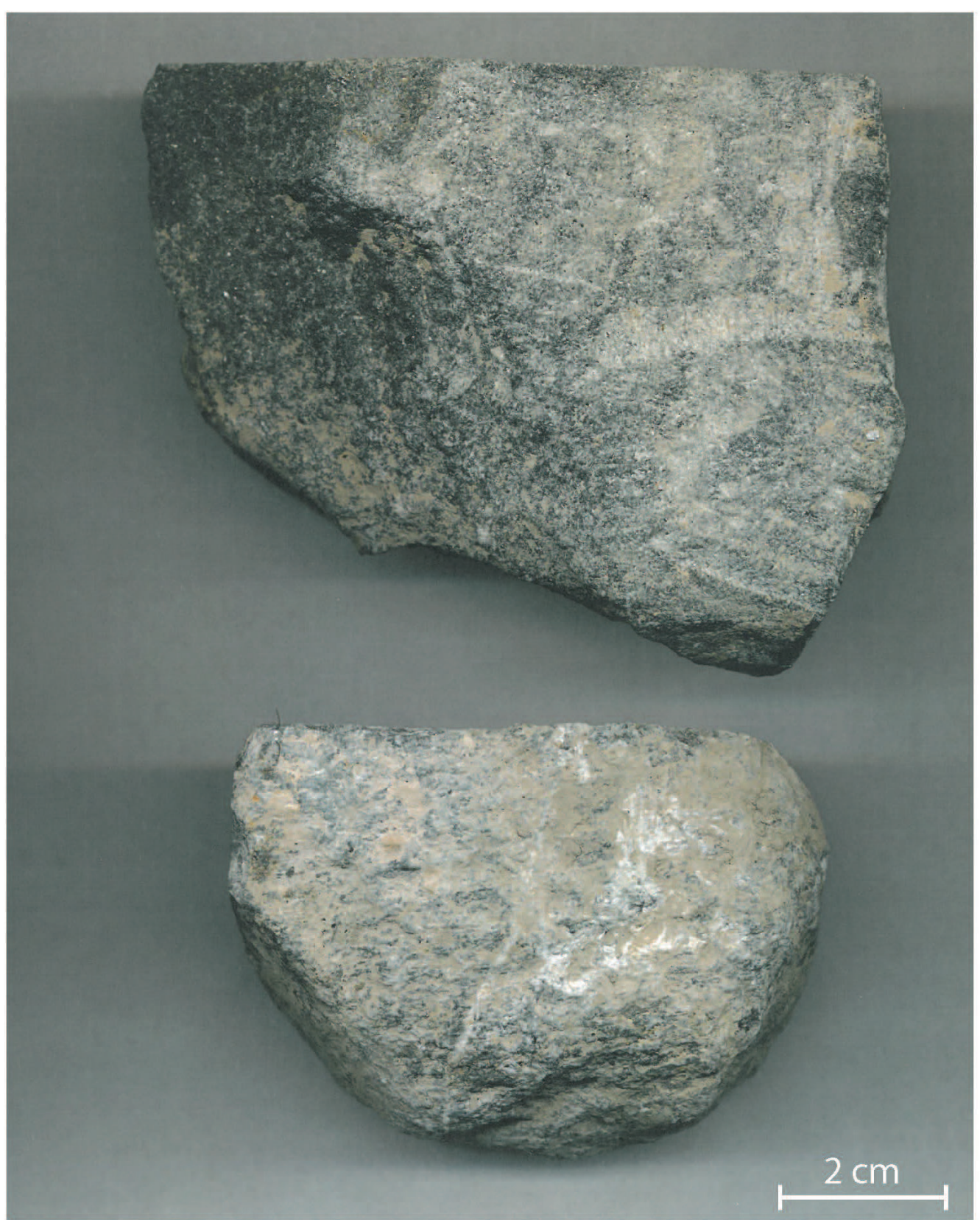

Figure 4. Two large ice-rafted clasts of metamorphic rocks (quartzite and gneiss) from the core in well $34 / 8-\mathrm{A}-33 \mathrm{H}$ (1124 mRKB). 


\section{Biostratigraphy}

\section{Micropaleontological analyses}

In the cored sections in all the investigated wells we have recorded a benthic foraminiferal Cibicides grossus assemblage. Other important benthic foraminifera include Nonion affine, Cibicides lobatulus, Cassidulina teretis and Elphidium excavatum (Eidvin \& Rundberg, 2001). The C. grossus assemblage correlates with Zone NSB 15 of King (1989, from the North Sea) which is of Gelasian to early Calabrian age. C. grossus was a shelf-dwelling form (Skarbø \& Verdenius, 1986) that is not recorded as in situ from scientific deep-sea boreholes in the Norwegian Sea. Consequently, its range is not calibrated directly with nannoplankton and palaeomagnetic data. According to King (1989 and personal communication), the range of $C$. grossus in the North Sea is based on correlation with planktonic foraminiferal taxa which are calibrated with nannoplankton and palaeomagnetic data in scientific deep-sea boreholes. Planktonic foraminifera recorded from the cores include Globigerina bulloides, Neogloboquadrina atlantica (sinistral), Neogloboquadrina atlantica (dextral) and Neogloboquadrina pachyderma (dextral; Eidvin \& Rundberg, 2001). Spiegler \& Jansen (1989) described a N. atlantica (sinistral) Zone from the $\bigvee \varnothing r i n g$ Plateau (Norwegian Sea) from upper Miocene to lower Pleistocene deposits. The LAD of $N$. atlantica (sinistral) in that area is approximately $2.4 \mathrm{Ma}$. It can be problematic to distinguish $N$. at lantica (sinistral) from the unencrusted form of Neogloboquadrina pachyderma (sinistral) near the youngest part of the distribution for $N$. atlantica (sinistral) since there are transitional forms. A G. bulloides Zone is described from the North Atlantic (DSDP Leg 94) in Pliocene and Pleistocene sediments as young as 2.2 Ma (Weaver \& Clement, 1986). On the Vøring Plateau, G. bulloides was common in Pliocene and Gelasian (lower Pleistocene) deposits older than 2.4 Ma (Spiegler \& Jansen, 1989). G. bulloides was also common during warm periods in the middle and upper Pleistocene (Kellogg, 1977). An upper N. atlantica (dextral) Zone is described from the Vøring Plateau in Gelasian deposits and is dated to 2.4-1.9 Ma (Spiegler \& Jansen, 1989). A Gelasian N. pachyderma (dextral) Zone is described by King (1989) from the North Sea, by Weaver (1987) and Weaver \& Clement (1986) from the North Atlantic and by Spiegler \& Jansen (1989) from the Vøring Plateau (Norwegian Sea). On the Vøring Plateau the zone is dated to 1.9-1.8 Ma.

\section{Palynological analyses}

Two core samples from each of the three wells; 34/8-A-1 H (1084.10 m, $1083.20 \mathrm{~m}), 34 / 8-\mathrm{A}-33 \mathrm{H}$ $(1125.80 \mathrm{~m}, 1124.80 \mathrm{~m})$ and 34/8-9 S (1112.53 m, $1109.70 \mathrm{~m})$ were analysed palynologically in order to date the cored intervals and to describe the contents of reworked deposits. Based on the dinocyst assemblages all three core intervals are referred to the Impletosphaeridium multiplexum Zone of Dybkjær \& Piasecki (2010). The age of this zone was suggested to be 2.6-1.6 Ma, Gelasian (early Pleistocene). The nominate species, Impletosphaeridium multiplexum, was not found. However, Bitectatodinium tepikiense, which appears in the lower part of this zone, are common, while Amiculosphaera umbraculum, the last occurrence of which defines the upper boundary of the I. multiplexum Zone, occur sporadically.

The presumed in situ dinocyst assemblages are dominated by Habibacysta tectata and Spiniferites spp., while Achomosphaera sp. Head 1996, Amiculosphaera umbracula, Bitectatodinium tepikiense and $B$. raedwaldii are common. Some of the specimens referred to $B$. tepikiense may belong to $B$. raedwaldii, as varieties of these species in some cases only can be separated using SEM. Frequent recordings of Filisphaera filifera are consistent with an age not younger than early Pleistocene, as this species has LAD at approximately 1.4 Ma (De Schepper \& Head, 2009). Sporadic occurrences of Tuberculodinium vancampoae further support an age not younger than the Gelasian (De Schepper \& Head, 2009). The frequent occurrences of Achomosphaera andalousiense, Nematosphaeropsis spp., Operculodinium centrocarpum and Spiniferites pseudofurcatus are also consistent with an early Pleistocene age although their ranges are much wider. The abundance in all the analysed samples of coldwater tolerant dinocyst species, including Bitectatodinium tepikiense, B. raedwaldii, Filisphaera filifera and Habibacysta tectata, are also consistent with a Pleistocene age. Especially the high abundances of the last-mentioned species are characteristic for the Gelasian in the eastern North Atlantic and the cored sections analysed in the present study may be referred to the RT7a-c biozones of De Schepper \& Head (2009) (2.57-2.08 Ma).

The number of reworked palynomorphs (spores, pollen and dinocysts) in the analysed samples varies. Dinocysts, spores and pollen are much smaller and lighter grains than, e.g., mollusc and foraminiferal tests and are much more easily transported and reworked. The reworked palynomorphs represent a 
broad range of time-intervals, from the Carboniferous to the Miocene, as outlined in Tables 4-6. Some of the recorded taxa has a short stratigraphic range, others a longer range. The following biostratigraphic literature was used for identifying the stratigraphic intervals from which the reworked palynomorphs came from; Lund (1977), Dybkjær (1988, 2004), Batten \& Koppelhus (1996), Bujak \& Mudge (1994), Heilmann-Clausen (1985, 1987), Manum et al. (1989), Riding \& Thomas (1992), De Verteuil \& Norris (1996), Eldrett et al. (2004), Heilmann-Clausen \& Van Simaeys (2005), Schiøler (2005), Schiøler et al. (2007), Traverse (2007), Dybkjær \& Piasecki (2010), Kürschner \& Herngreen (2010), Sliwinska et al. (2012), Egger et al. (2016) and Dybkjær et al. (2020).

\section{Sr isotope stratigraphy}

Each of the five samples in well 34/8-9 S, seven samples in 34/8-A-1 $\mathrm{H}$ and four samples in well 34/8A-33 $\mathrm{H}$ were analysed from two to five times for control purposes. Data from eighteen of the samples in wells 34/8-9 S and 34/8-A-1 H were analysed for Eidvin \& Rundberg (2001). The remaining 14 and all the samples from well $34 / 8-\mathrm{A}-33 \mathrm{H}$ were analysed for the present study. The obtained ${ }^{87} \mathrm{Sr} /{ }^{86} \mathrm{Sr}$ ratios gave ages that varied between 1.8 and 6.3 Ma (Tables 1-3; Fig. 5). We assume that the large variations in estimated ages, also within the same samples, for a significant part are due to the uncertainty in calculation of ages from the flat, latest Pliocene to earliest Pleistocene part of the Sr curve (Fig. 2). An additional factor may be that some of the analysed foraminifera and mollusc tests may be reworked from upper Miocene and lower Pliocene deposits, since the sediments consist mainly of contourite deposits and are allochthonous sediments. Most of the analysed benthic foraminifera have long ranges and dwelled from the late Miocene to the Pleistocene, but we have not recorded foraminifera which have ranges limited to the late Miocene to early Pliocene (so-called index forms). However, the palynological data indicate that reworked late Miocene to early Pliocene sediments are present in the samples (Tables 4-6). Consequently, the large variations in estimated ages can be due to both the uncertainty in calculation of ages from a flat $\mathrm{Sr}$ curve and to reworked calcareous fossil tests.

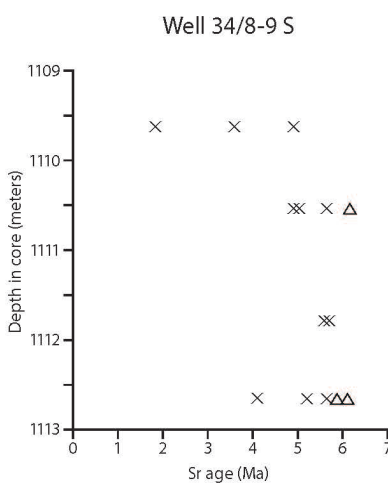

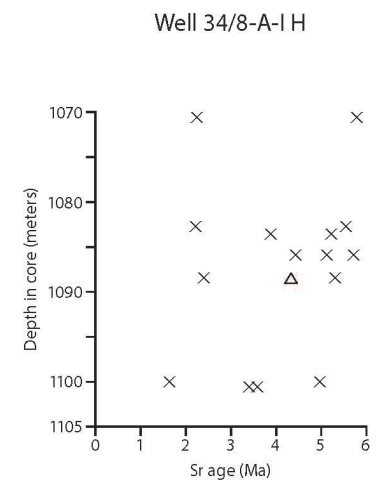

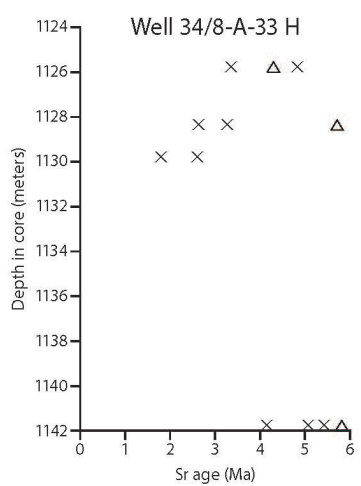

$X=S$ r analyses based on foraminiferal test $\Delta=S r$ analyses based on mollusc fragments

Figure 5. Plots of the Sr data from the short cores in the basal Pleistocene unit in the Visund wells 34/8-9 S (A), 34/8-A-1 $H(B)$ and 34/8-A-33 H (C) according to Tables 1-3. The plots are based on the ages obtained from the look-up table of Howarth \& McArthur (1997) and show mean values.

\section{Seismic stratigraphy and correlation to the $\mathrm{Sr}$ samples}

The Tampen area where the Visund and Snorre wells are located comprises a thick unit of prograding clinoforms which are interpreted to be glacigenic debris flows deposited from an ice sheet covering the land areas of Norway and adjacent shelf during early and middle Quaternary (Ottesen et al., 2014; Batchelor et al., 2017; Figs. 1 \& 6). Below the prograding clinoforms and above the base Quaternary horizon, there is a flat-lying package of mainly silty mudstones and fine-grained sandstones. The package was called the "Basal Upper Pliocene Unit" by Eidvin \& Rundberg, 2001 (based on the time scale of Berggren et al. (1995)). Well 34/8-A-33 H penetrates both the "Basal Upper Pliocene Unit" and the unit of prograding clinoforms (Fig. 6). All the samples were taken in the "Basal Upper Pliocene Unit", located between $1125.8 \mathrm{~m}$ and $1141.8 \mathrm{~m}$ depth. 


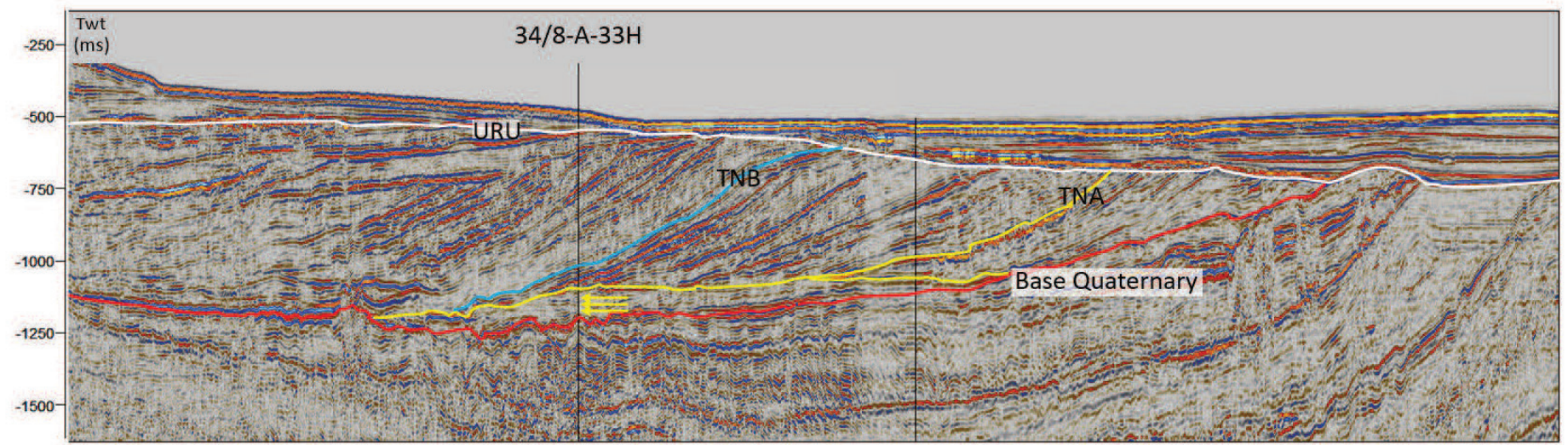

Figure 6. Seismic profile through well 34/8-A-33 H (northern North Sea) with interpreted Pleistocene seismic reflectors (from Ottesen et al., 2014) and levels for Sr sampling (yellow arrows). TWT means two-way travel time. Location of the line is shown in Fig. 1.

\section{Area 2; well 16/1-4 from the southern Viking Graben in the northern North Sea}

Eidvin \& Rundberg (2007) investigated drill-cutting and sidewall core samples in the lower Oligocene to middle Pleistocene succession in the exploration well 16/1-4 (58 $51^{\circ} 55.20^{\prime \prime} \mathrm{N}, 02^{\circ} 17^{\prime} 56.12^{\prime \prime} \mathrm{E}$, Fig. 1) by means of micropaleontological and lithological stratigraphy. The lower Oligocene to lower Miocene part of the succession (Hordaland Group and Skade Formation) was also investigated by means of $\mathrm{Sr}$ isotope stratigraphy. For the present study we have investigated 14 sidewall core samples from the upper part of the lower Pliocene to the middle Pleistocene by means of $\mathrm{Sr}$ isotope stratigraphy. Two of the samples are from the uppermost part of the Utsira Formation and twelve samples are from the lower and middle part of the Naust Formation (Table 7; Fig. 7; Eidvin \& Rundberg, 2007).

\section{Lithology}

The two sidewall cores from the Utsira Formation consist mainly of quartzose sandstones with minor glauconite and mollusc fragments. The sidewall cores from the Naust Formation consist mainly of immature, poorly sorted mudstones with sand. Apart from quartz and feldspar grains, the sand fraction contains a high proportion of granitic and metamorphic rock fragments and pebbles; and mollusc fragments are also recorded especially in the upper part (Fig. 7; Eidvin \& Rundberg, 2007).

\section{Biostratigraphy}

The sediments in the two sidewall cores from the Utsira Formation (Table 7) are given an early Pliocene age based on benthic foraminifera of the Uvigerina venusta saxonica assemblage and planktonic foraminifera of the Globorotalia puncticulata assemblage (Fig. 7). The benthic foraminiferal fauna also includes Florilus bouanus and Sphaeroidina bulloides. The planktonic foraminiferal fauna also includes Globigerina bulloides and Neogloboquadrina atlantica (sinistral; Eidvin \& Rundberg, 2007; Eidvin et al., 2013). The benthic foraminiferal fauna is correlated with the upper part of Subzone NSB 13b of King (1989, from the North Sea). A Pliocene G. puncticulata assemblage has been described by Weaver \& Clement (1986) from the North Atlantic. The FAD of G. puncticulata in that area is at approximately 4.6 $\mathrm{Ma}$ and its LAD is at approximately $2.5 \mathrm{Ma}$.

The twelve samples from the lower and middle parts of the Naust Formation are given an early to middle Pleistocene age based on benthic foraminifera of the Cibicides grossus assemblage and Elphidium excavatum - Cassidulina teretis assemblage, and planktonic foraminifera of the Neogloboquadrina atlantica (sinistral) assemblage, Neogloboquadrina atlantica (dextral) assemblage and Neogloboquadrina pachyderma (dextral) assemblage (Fig. 7; Eidvin \& Rundberg, 2007). 
Table 7. Sr isotope data from well 16/1-4. The samples were analysed at the University of Bergen. Sr ratios were corrected to NIST 987 = 0.710248. Numerical ages derived from the SIS look-up tables of Howarth \& MCArthur (1997, 2004). NIST - National Institute for Standard and Technology.

\begin{tabular}{|c|c|c|c|c|c|c|}
\hline $\begin{array}{l}\text { Litho. } \\
\text { Unit }\end{array}$ & $\begin{array}{l}\text { Sample } \\
\text { depth } \\
\text { (SWC) }\end{array}$ & $\begin{array}{l}\text { Corrected } \\
{ }^{87 / 86} \mathrm{Sr}\end{array}$ & $2 \mathrm{~S}$ error & $\begin{array}{l}\text { Age (Ma; } \\
\text { H\&M, 1997; } \\
\text { mean value) }\end{array}$ & $\begin{array}{l}\text { Age (Ma; } \\
\text { H\&M, 2004; } \\
\text { mean value) }\end{array}$ & Analysed fossils \\
\hline $\begin{array}{l}\text { Naust } \\
\text { Fm. }\end{array}$ & $357.5 \mathrm{~m}$ & 0.709126 & 0.000009 & 1.192 & 1.190 & $\begin{array}{l}\text { Ca. } 25 \text { tests of E. excavatum, C. teretis, H. orbiculare, } \\
\text { E. ustulatum, B. marginata }\end{array}$ \\
\hline $\begin{array}{l}\text { Naust } \\
\text { Fm. }\end{array}$ & $357.5 \mathrm{~m}$ & 0.709133 & 0.000009 & 1.110 & 1.086 & $\begin{array}{l}\text { Ca. } 30 \text { tests of E. excavatum, C. teretis, H. orbiculare, } \\
\text { E. ustulatum }\end{array}$ \\
\hline $\begin{array}{l}\text { Naust } \\
\text { Fm. }\end{array}$ & $357.5 \mathrm{~m}$ & 0.709198 & 0.000032 & 0 & 0 & Ca. 30 tests of E. excavatum, H. orbiculare, E. ustulatum \\
\hline $\begin{array}{l}\text { Naust } \\
\text { Fm. }\end{array}$ & $357.5 \mathrm{~m}$ & 0.70120 & 0.000009 & 1.265 & 1.272 & One mollusc fragment \\
\hline $\begin{array}{l}\text { Naust } \\
\text { Fm. }\end{array}$ & $454.5 \mathrm{~m}$ & 0.709118 & 0.000009 & 1.289 & 1.297 & Ca. 30 testsd of C. teretis \\
\hline $\begin{array}{l}\text { Naust } \\
\text { Fm. }\end{array}$ & $454.5 \mathrm{~m}$ & 0.709142 & 0.000009 & 0.924 & 0.920 & 31 tests of $C$. teretis \\
\hline $\begin{array}{l}\text { Naust } \\
\text { Fm. }\end{array}$ & $\begin{array}{l}454.5+ \\
480.5 \mathrm{~m}\end{array}$ & 0.709133 & 0.000008 & 1.110 & 1.086 & $\begin{array}{l}23 \text { tests of } E \text {. groenlandicum and ca. } 40 \text { tests of } \\
\text { E. excavatum, Epistominella sp., V. loeblichi, B. marginata }\end{array}$ \\
\hline $\begin{array}{l}\text { Naust } \\
\text { Fm. }\end{array}$ & $480.5 \mathrm{~m}$ & 0.709140 & 0.000009 & 0.986 & 0.965 & $\begin{array}{l}\text { Ca. } 33 \text { tests of } E \text {. excavatum, C. teretis, N. affine, Elphidium } \\
\text { sp. }\end{array}$ \\
\hline $\begin{array}{l}\text { Naust } \\
\text { Fm. }\end{array}$ & $480.5 \mathrm{~m}$ & 0.709174 & 0.000009 & 0.038 & 0.080 & $\begin{array}{l}\text { Ca. } 40 \text { tests of E.excavatum, C. teretis, N. affine, Elphidium } \\
\text { sp. }\end{array}$ \\
\hline $\begin{array}{l}\text { Naust } \\
\text { Fm. }\end{array}$ & $536.5 \mathrm{~m}$ & 0.709107 & 0.000008 & 1.423 & 1.461 & 35 tests of $C$. teretis \\
\hline $\begin{array}{l}\text { Naust } \\
\text { Fm. }\end{array}$ & $536.5 \mathrm{~m}$ & 0.709124 & 0.000009 & 1.216 & 1.218 & 38 tests of C.teretis \\
\hline $\begin{array}{l}\text { Naust } \\
\text { Fm. }\end{array}$ & $536.5 \mathrm{~m}$ & 0.709129 & 0.000009 & 1.158 & 1.146 & Ca. 30 tests of C. teretis \\
\hline $\begin{array}{l}\text { Naust } \\
\text { Fm. }\end{array}$ & $574.5 \mathrm{~m}$ & 0.709095 & 0.000008 & 1.688 & 1.695 & $\begin{array}{l}\text { Ca. } 30 \text { tests of E. groenlandicum, E. excavatum, N. affine, } \\
\text { C. teretis }\end{array}$ \\
\hline $\begin{array}{l}\text { Naust } \\
\text { Fm. }\end{array}$ & $574.5 \mathrm{~m}$ & 0.709098 & 0.000008 & 1.598 & 1.631 & $\begin{array}{l}\text { Ca. } 40 \text { tests of } C \text {. terets, N. affine, E. groenlandicum, } \\
\text { C. lobatulus }\end{array}$ \\
\hline $\begin{array}{l}\text { Naust } \\
\text { Fm. }\end{array}$ & $574.5 \mathrm{~m}$ & 0.709086 & 0.000009 & 1.98 & 1.97 & 33 tests of $C$. teretis \\
\hline $\begin{array}{l}\text { Naust } \\
\text { Fm. }\end{array}$ & $613.5 \mathrm{~m}$ & 0.709125 & 0.000010 & 1.204 & 1.205 & 35 tests of $C$. teretis \\
\hline $\begin{array}{l}\text { Naust } \\
\text { Fm. }\end{array}$ & $613.5 \mathrm{~m}$ & 0.709126 & 0.000009 & 1.192 & 1.190 & Ca. 40 tests of C. teretis \\
\hline $\begin{array}{l}\text { Naust } \\
\text { Fm. }\end{array}$ & $613.5 \mathrm{~m}$ & 0.709121 & 0.000009 & 1.253 & 1.258 & 30 tests of E. excavatum, E. albiumbilicatum, N. affine \\
\hline $\begin{array}{l}\text { Naust } \\
\text { Fm. }\end{array}$ & $646.5 \mathrm{~m}$ & 0.709121 & 0.000008 & 1.253 & 1.258 & 35 tests of $C$. teretis, E. hannai \\
\hline $\begin{array}{l}\text { Naust } \\
\text { Fm. }\end{array}$ & $646.5 \mathrm{~m}$ & 0.709224 & $\begin{array}{l}0.000011 \\
\text { (quite high } \\
\text { standard } \\
\text { deviation) }\end{array}$ & 0 & 0 & $\begin{array}{l}36 \text { tests of } C \text {. teretis, E. excavatum, E. albiumbilicatum, } \\
\text { Epistominella sp., Elphidium sp., } H \text {. orbiculare }\end{array}$ \\
\hline $\begin{array}{l}\text { Naust } \\
\text { Fm. }\end{array}$ & $673.5 \mathrm{~m}$ & 0.709135 & 0.000009 & 1.084 & 1.056 & 40 tests of $C$. teretis \\
\hline $\begin{array}{l}\text { Naust } \\
\text { Fm. }\end{array}$ & $673.5 \mathrm{~m}$ & 0.709118 & 0.000009 & 1.289 & 1.297 & $\begin{array}{l}\text { Ca. } 40 \text { tests of } C \text {. teretis, } N \text {. affine, E. albiumbilicatum, } \\
\text { E. excavatum, } H \text {. orbiculare, Lagena sp., B. tenerrima }\end{array}$ \\
\hline
\end{tabular}




\begin{tabular}{|c|c|c|c|c|c|c|}
\hline $\begin{array}{l}\text { Naust } \\
\text { Fm. }\end{array}$ & $673.5 \mathrm{~m}$ & 0.709069 & 0.000009 & 2.57 & 2.54 & $\begin{array}{l}31 \text { tests of } C \text {. grossus, } Q \text {. seminulum, C. teretis, one molluc } \\
\text { fragment }\end{array}$ \\
\hline $\begin{array}{l}\text { Naust } \\
\text { Fm. }\end{array}$ & $681.5 \mathrm{~m}$ & 0.709099 & 0.000009 & 1.572 & 1.611 & Ca. 40 tests of C. teretis, C. grossus, Elphidium sp. \\
\hline $\begin{array}{l}\text { Naust } \\
\text { Fm. }\end{array}$ & $681.5 \mathrm{~m}$ & 0.709105 & 0.000009 & 1.450 & 1.497 & 38 tests of $C$. teretis, $N$. affine, $C$. lobatulus \\
\hline $\begin{array}{l}\text { Naust } \\
\text { Fm. }\end{array}$ & $681.5 \mathrm{~m}$ & 0.709134 & 0.000010 & 1.098 & 1.072 & 38 tests of $C$. teretis; $C$. lobatulus \\
\hline $\begin{array}{l}\text { Naust } \\
\text { Fm. }\end{array}$ & $685.5 \mathrm{~m}$ & 0.709090 & 0.000009 & 1.84 & 1.83 & Ca. 45 tests of $C$. teretis \\
\hline $\begin{array}{l}\text { Naust } \\
\text { Fm. }\end{array}$ & $685.5 \mathrm{~m}$ & 0.709093 & 0.000009 & 1.75 & 1.74 & 40 tests of $C$. teretis \\
\hline $\begin{array}{l}\text { Naust } \\
\text { Fm. }\end{array}$ & $685.5 \mathrm{~m}$ & 0.709106 & 0.000009 & 1.436 & 1.478 & Ca. 40 tests of $C$. teretis \\
\hline $\begin{array}{l}\text { Naust } \\
\text { Fm. }\end{array}$ & $688.5 \mathrm{~m}$ & 0.709074 & 0.000009 & 2.37 & 2.36 & Ca. 40 tests of $C$. grossus, Q. seminulum, C. teretis, $N$. affine \\
\hline $\begin{array}{l}\text { Naust } \\
\text { Fm. }\end{array}$ & $688.5 \mathrm{~m}$ & 0.709117 & 0.000009 & 1.301 & 1.310 & Ca. 35 tests of C. teretis, N. affine, C. grossus \\
\hline $\begin{array}{l}\text { Naust } \\
\text { Fm. }\end{array}$ & $688.5 \mathrm{~m}$ & 0.709073 & 0.000009 & 2.41 & 2.39 & Ca. 35 tests of C. teretis, N. affine \\
\hline $\begin{array}{l}\text { Naust } \\
\text { Fm }\end{array}$ & $732.5 \mathrm{~m}$ & 0.709038 & 0.000009 & 4.97 & 4.93 & $\begin{array}{l}\text { Ca. } 50 \text { tests of } C \text {. teretis, Q. seminulum, E. excavatum, } \\
\text { N. affine, C. grossus }\end{array}$ \\
\hline $\begin{array}{l}\text { Naust } \\
\text { Fm }\end{array}$ & $732.5 \mathrm{~m}$ & 0.709074 & 0.000008 & 2.37 & 2.36 & Ca 40 tests of $C$. teretis, N. affine \\
\hline $\begin{array}{l}\text { Naust } \\
\text { Fm }\end{array}$ & $732.5 \mathrm{~m}$ & 0.709089 & 0.000009 & 1.87 & 1.86 & 36 tests of $C$. teretis \\
\hline $\begin{array}{l}\text { Naust } \\
\text { Fm }\end{array}$ & $763.5 \mathrm{~m}$ & 0.709063 & 0.000009 & 3.38 & 2.84 & $\begin{array}{l}42 \text { tests of B. marginata, L. lammersi, E. excavatum, } \\
\text { M. pseudotepida, N. affine, A. fluens, Dentalina sp., } \\
\text { C. teretis, P. bulloides, S. bulloides }\end{array}$ \\
\hline $\begin{array}{l}\text { Naust } \\
\text { Fm }\end{array}$ & $763.5 \mathrm{~m}$ & 0.709081 & 0.000009 & 2.15 & 2.15 & $\begin{array}{l}35 \text { tests of } B . \text { marginata, L. lammersi, M. pseudotepida, } N \text {. } \\
\text { affine, A. fluens, P. bulloides, S. bulloides, G. gibba rugose }\end{array}$ \\
\hline $\begin{array}{l}\text { Naust } \\
\text { Fm }\end{array}$ & $763.5 \mathrm{~m}$ & 0.709082 & 0.000009 & 2.12 & 2.12 & $\begin{array}{l}46 \text { tests of S. bulloides, N. affine, A. fluens, C. dutemplei, } \\
\text { B. marginata, P. bulloides, M. pseudotepida, fish teeth }\end{array}$ \\
\hline $\begin{array}{l}\text { Naust } \\
\text { Fm }\end{array}$ & $765.5 \mathrm{~m}$ & 0.709079 & 0.000009 & 2,21 & 2.21 & $\begin{array}{l}28 \text { tests of } U . \text { venusta saxonica, C. pachyderma, } \\
\text { C. lobatulus, B. marginata, M. pseudotepida }\end{array}$ \\
\hline $\begin{array}{l}\text { Utsira } \\
\text { Fm. }\end{array}$ & $767.5 \mathrm{~m}$ & 0.709052 & 0.000009 & 4.21 & 4.11 & $\begin{array}{l}34 \text { tests of U. venusta saxonica, N. koninckii, P. bulloides, } \\
\text { C. pachyderma, S. bulloides, B. marginata, N.affine, } \\
\text { C. lobatulus, M. pseudotepida }\end{array}$ \\
\hline $\begin{array}{l}\text { Utsira } \\
\text { Fm. }\end{array}$ & $767.5 \mathrm{~m}$ & 0.709100 & $\begin{array}{l}0.000012, \\
\text { (quite high } \\
\text { standard } \\
\text { deviation) }\end{array}$ & 1.546 & 1.591 & $\begin{array}{l}27 \text { tests of } U . \text { venusta saxonica, } P \text {. bulloides, } C \text {. } \\
\text { pachyderma, B. marginata, C. lobatulus, M. pseudotepida }\end{array}$ \\
\hline $\begin{array}{l}\text { Utsira } \\
\text { Fm. }\end{array}$ & $768.5 \mathrm{~m}$ & 0.708999 & 0.000009 & 5.84 & 5.91 & $\begin{array}{l}8 \text { tests of } B . \text { marginata, Cibicides sp., N. affine, Guttulina } \\
\text { sp, Ostracoda }\end{array}$ \\
\hline
\end{tabular}




\section{WELL 16/1-4}

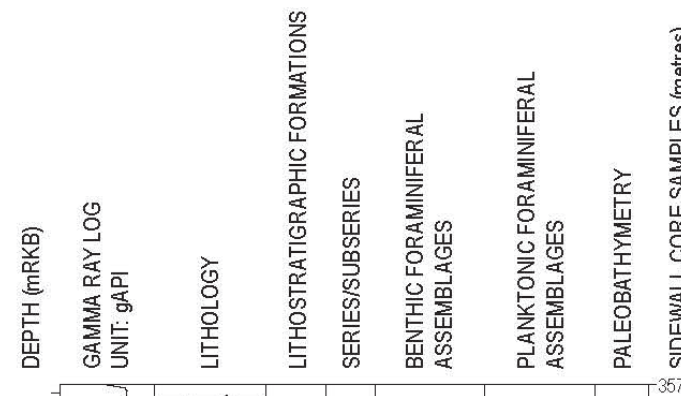

SR DATA PLOTS

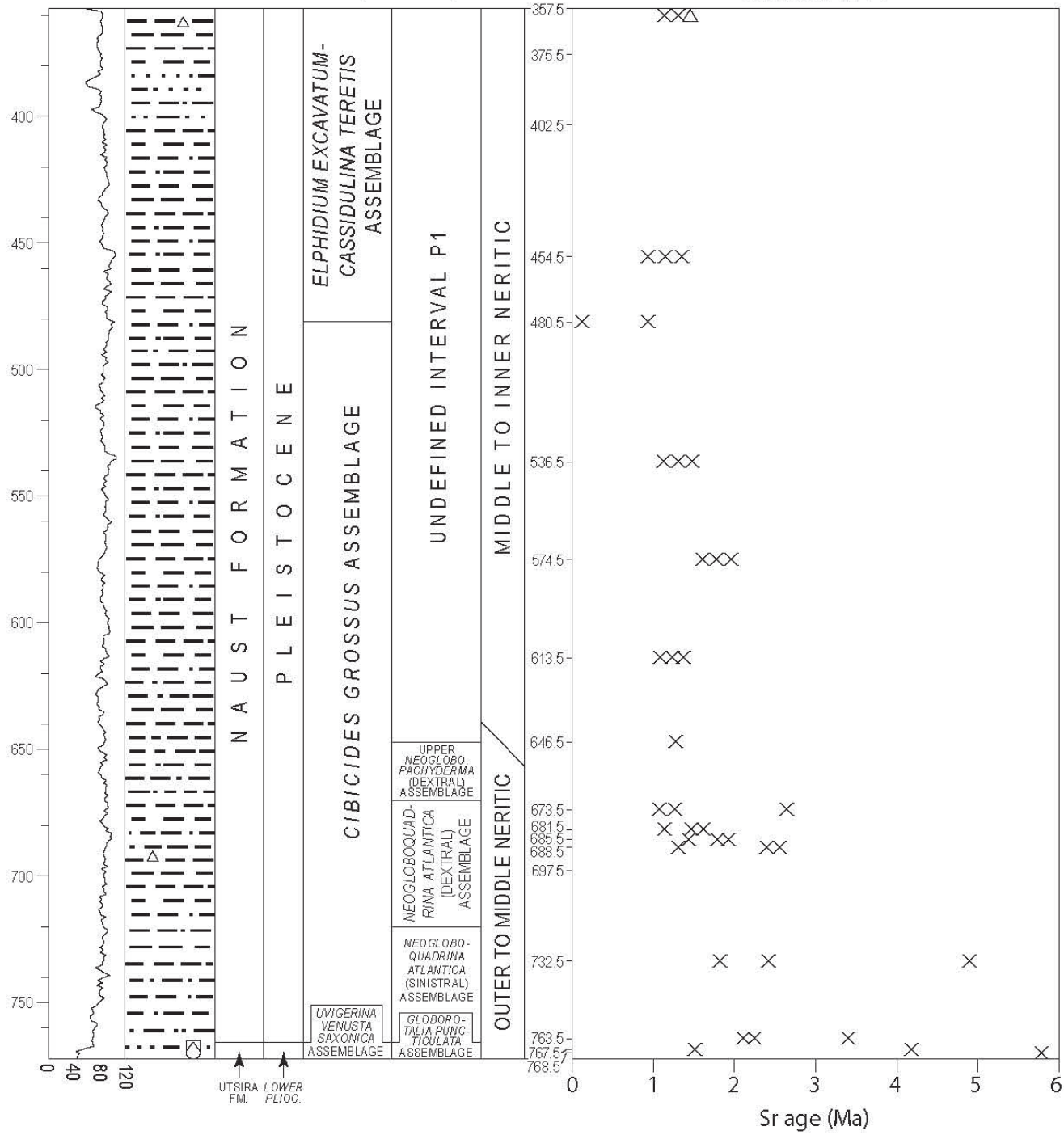

Water depth: $384 \mathrm{M}$ (MSL)

$X=\mathrm{Sr}$ analyses based on foraminiferal tests $\triangle=\mathrm{Sr}$ analyses based on mollusc fragments

Figure 7. Well summary figure including lithology, gamma-ray log, lithostratigraphic units, series/subseries, benthic foraminiferal assemblages, planktonic foraminiferal assemblages, paleobathymetry, analysed samples and $\mathrm{Sr}$ data plots for well 16/1-4 (according to Table 7). The plots are based on the ages obtained from the look-up table of Howarth \& McArthur (1997) and show mean values. 
The C. grossus assemblage correlates with Zone NSB 15 of King (1989; North Sea) which is of Gelasian to early Calabrian age. The Elphidium excavatum - Cassidulina teretis assemblage correlates with Subzone NSB 16x of King (1989) which is of late Calabrian age. Spiegler \& Jansen (1989) described $a$ N. atlantica (sinistral) Zone from the Vøring Plateau (Norwegian Sea) from upper Miocene to lower Pleistocene deposits. The LAD of $N$. atlantica (sinistral) in that area is at approximately $2.4 \mathrm{Ma}$. An upper N. atlantica (dextral) Zone is described from the Vøring Plateau in Gelasian deposits and is dated to 2.4-1.9 Ma (Spiegler \& Jansen, 1989). A Gelasian N. pachyderma (dextral) Zone is described by King (1989) from the North Sea, by Weaver (1987) and Weaver \& Clement (1986) from the North Atlantic and by Spiegler \& Jansen (1989) from the Vøring Plateau. On the Vøring Plateau the zone is dated to 1.9-1.8 Ma. Based on the occurrence of a few specimens of Monspeliensina pseudotepida in the samples at 765.5 and $763.3 \mathrm{~m}$, one cannot rule out the possibility that there is a thin, condensed, upper Piacenzian (uppermost Pliocene) unit at the base of the Naust Formation. According to King (1989), the last occurrence datum of $M$. pseudotepida is in the upper Piacenzian.

\section{Sr isotope stratigraphy}

If enough calcareous fossil tests were present, most of the 14 sidewall core samples were analysed three times for control purposes (Table 7; Fig. 7). The sample from $768.5 \mathrm{~m}$ from the Utsira Formation gave 5.8 Ma based on the Sr look-up table of Howarth \& McArthur (1997) and 5.9 Ma based on the look-up table of Howarth \& McArthur (2004) (late Messinian). The sample from $767.5 \mathrm{~m}$ from the Utsira Formation gave 4.2 Ma based on the Sr look-up table of Howarth \& McArthur(1997) and 4.1 Ma based on the look-up table of Howarth \& McArthur (2004) (early Zanclean). A second analysis of the sample from $767.5 \mathrm{~m}$ gave 1.5 Ma based on the look-up table of Howarth \& McArthur (1997) and 1.6 Ma based on the table of Howarth \& McArthur (2004) (early Calabrian), but this analysis gave a quite high standard deviation and the obtained ${ }^{87} \mathrm{Sr} /{ }^{86} \mathrm{Sr}$ ratio and resulting age are probably wrong. The ${ }^{87} \mathrm{Sr} /{ }^{86} \mathrm{Sr}$ ratios obtained from all the samples from the Naust Formation, from 765.5 to $357.5 \mathrm{~m}$, plot on most parts of the Sr isotope curve for the Pleistocene. The obtained ages gave a quite large spread with older above younger ages in some cases. There are also some variations in ages within the same samples. The ages range from 5.0 to $1.1 \mathrm{Ma}$ and show a tendency of increasing age with increasing depth, but not a clear tendency. However, most of the samples from the lower part of the Naust Formation gave ages of approximately 2.4 to $2.1 \mathrm{Ma}$, while most of the samples from the upper part of the Naust Formation unit gave ages of 1.3 to $1.0 \mathrm{Ma}$ (Table 7; Fig. 7). Since caved fossil tests most likely can be excluded in the sidewall core samples, the fact that the $\mathrm{Sr}$ data show a somewhat uneven age distribution is most likely the result of the unfavourable form of the Pleistocene part of the Sr seawater curve. However, the Zanclean age of the sample from $732.5 \mathrm{~m}$ is probably due to the presence of reworked foraminiferal tests, and the recent ages of the sample from 646.5 and $357.5 \mathrm{~m}$ are probably due to quite high standard deviations (Table 7).

\section{Seismic stratigraphy and correlation to the Sr samples}

This area represents the transitional area between the northern and central North Sea. In this area the Quaternary North Sea Basin is rather narrow (Ottesen et al., 2014) and up to $700 \mathrm{~m}$ deep. This part of the basin is filled up with a series of prograding clinoforms, which have a more fluvial character in contrast to the glacigenic units in the northern North Sea (Figs. 8 and 10). Well 16/1-4 is located in the deepest part of the basin, comprising flat-lying units of fine-grained sediments (Fig. 1). This well is sampled at 14 different depths between 357.5 and $768.5 \mathrm{~m}$. All samples except the two lowermost (Utsira Formation) are from the Pleistocene Naust Formation. The three clinoform units mapped by Ottesen et al. (2014) are sampled in addition to the central basin unit above clinoform unit 3 (Fig. 8). Ottesen et al. (2018) have assigned these units to the lower Pleistocene based on regional considerations. 


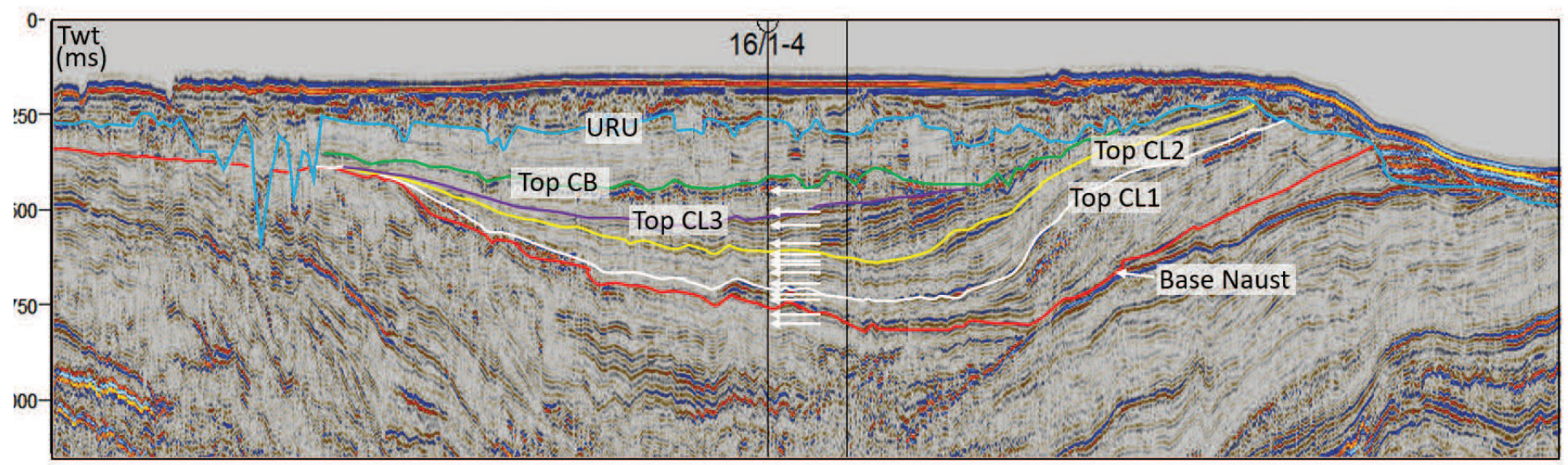

Figure 8. Seismic profile through well 16/1-4 (northern North Sea) with interpreted Pleistocene seismic reflectors (from Ottesen et al., 2014) and levels for Sr sampling (white arrows). According to Ottesen et al. (2018), all these three units (Unit 1, between Base Naust and Top CL1, Unit 2, between top Clinoform 1 and Top Clinoform 2, and Unit 3 between Top CL2 and Top CL3) are of early Pleistocene age based on regional considerations. TWT means two-way travel time. Location of the line is shown in Fig. 1.

\section{Area 3; well 35/2-1 (Peon gas discovery) from the Tampen area in the northern North Sea}

Norsk Hydro (now Equinor) proved the Peon gas discovery in the exploration well $35 / 2-1\left(61^{\circ} 53^{\prime} 26.68^{\prime \prime} \mathrm{N}\right.$, $03^{\circ} 20^{\prime} 34.36^{\prime \prime} \mathrm{E}$; Fig. 1) in a sandy glacimarine depositional system at about $165 \mathrm{~m}$ below the sea floor (574 $\mathrm{m}$ below the drill table (mRKB) (Carstens, 2005)). The depositional system is situated directly above the angular mid Pleistocene unconformity (Upper Regional Unconformity (URU)). The well was drilled from 384 to $713 \mathrm{~m}$ in the northern part of the Norwegian Channel and, according to Carstens (2005), Norsk Hydro described a situation where subglacial rivers deposited delta-like sediments in the area where the north-flowing ice stream met deep water in the Norwegian Sea.

Eidvin (2005) investigated ditch-cutting samples from the succession in well 35/2-1 (546 to $711 \mathrm{~m}$; Fig. 9). No conventional cores and sidewall cores were sampled in this well. Twenty-two ditch-cutting samples were investigated by means of micropaleontology and lithology (Eidvin, 2005). For the present study we have investigated four of these samples by means of Sr isotope stratigraphy (see Table 8 and Fig. 9).

\section{Lithology}

The samples from 546 to $564 \mathrm{~m}$ consist mainly of poorly sorted, mudstone-dominated, glacigenic diamictons with sand and some pebbles of metamorphic and granitic rocks. The samples 573 to $621 \mathrm{~m}$ consist mainly of sand. Most of the sand grains are quartzose but glauconitic grains are also recorded throughout the section. Some pebbles of metamorphic and granitic rocks and mollusc fragments are also recorded throughout the section. The samples from 624 to $711 \mathrm{~m}$ consist mainly of poorly sorted sand and mudstone-dominated glacigenic diamictons with some pebbles of metamorphic and granitic rocks and mollusc fragments.

\section{Biostratigraphy}

In the samples from 711 to $621 \mathrm{~m}$, Eidvin (2005) recorded a benthic foraminiferal Elphidiella hannai assemblage. The assemblage also includes Elphidium excavatum, Elphidium albiumbilicatum, Nonion affine, Bulimina marginata, Haynesina orbiculare and Cibicides lobatulus (Eidvin, 2005). The E. hannai assemblage correlates with Zone NSB 15 of King (1989) which is of Gelasian to early Calabrian age. E. hannai was a shallow-marine form (Skarb $\varnothing$ \& Verdenius, 1986) that has not been recorded from scientific deep-sea boreholes in the Norwegian Sea. Consequently, its range is not calibrated directly 


\section{WELL 35/2-1}

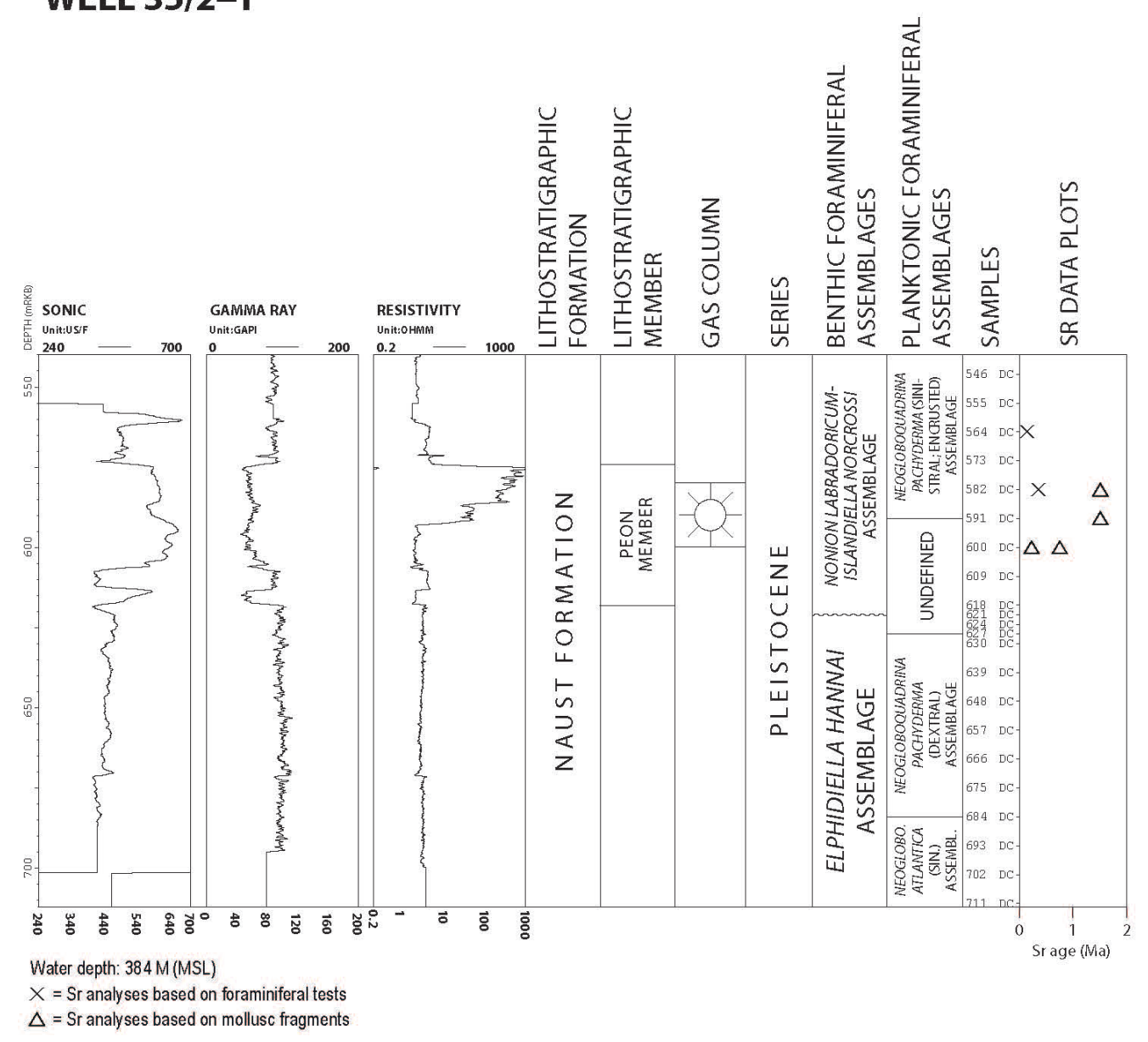

Figure 9. Well summary figure including sonic, gamma-ray and resistivity logs, lithostratigraphic units, gas column, series, benthic foraminiferal assemblages, planktonic foraminiferal assemblages, analysed samples and Sr data plots for well 35/2-1 (according to Table 8). The plots are based on the ages obtained from the look-up table of Howarth \& McArthur (1997) and show mean values. M MSL - metres below mean sea level, gAPI - American Petroleum Institute gamma-ray units (modified after Eidvin 2005).

with nannoplankton and palaeomagnetic data. As for the range of $C$. grossus (see above), according to King (1989 and personal communication), the range of E. hannai in the North Sea is based on correlation with planktonic foraminiferal taxa which are calibrated with nannoplankton and palaeomagnetic data in scientific deep-sea boreholes.

In the samples from 711 to $684 \mathrm{~m}$, Eidvin (2005) also recorded a planktonic Neogloboquadrina atlantica (sinistral) assemblage. The $N$. atlantica (sinistral) assemblage also includes Globigerina bulloides and Neogloboquadrina atlantica (dextral (one specimen)) (Eidvin, 2005). N. atlantica (sinistral) is known from the North Atlantic and the Vøring Plateau (Norwegian Sea) in upper Miocene to lower Pleistocene sediments. The LAD of this species in both areas is approximately $2.4 \mathrm{Ma}$ (Weaver \& Clement, 1986; Spiegler \& Jansen, 1989). In the samples from 684 to $627 \mathrm{~m}$, Eidvin (2005) recorded a planktonic Neogloboquadrina pachyderma (dextral) assemblage. The assemblage also includes a few specimens of unencrusted forms of $N$. pachderma (sinistral), G. bulloides and Globorotalia inflata (Eidvin, 2005). An early Pleistocene N. pachyderma (dextral) Zone is described by King (1989) from the North Sea, by Weaver \& Clement (1986) from the North Atlantic and by Spiegler \& Jansen (1989) from the Vøring Plateau. On the Vøring Plateau the zone is dated to 1.9 to $1.8 \mathrm{Ma}$. The zone is characterised by common N. pachyderma (dextral). However, N. pachyderma (dextral) was also known, in smaller numbers, from warm periods during the late part of the Pleistocene (Kellogg, 1977; Spiegler \& Jansen, 1989). 
In the samples from 621 to $546 \mathrm{~m}$, Eidvin (2005) recorded a benthic foraminiferal Nonion labradoricum - Islandiella norcrossi assemblage. The assemblage also includes Elphidium excavatum, Bulimina marginata, Haynesina orbiculare, Cassidulina teretis and Elphidium albiumbilicatum (Eidvin, 2005). The assemblage correlates with Subzone NSB 16x of King (1989) which is of late Calabrian age.

In the samples from 591 to 546 m, Eidvin (2005) also recorded a Neogloboquadrina pachyderma (sinistral; encrusted form) assemblage. A few specimens of G. bulloides, N. pachyderma (dextral) and Turborotalia quinqueloba were also recorded in some samples (Eidvin, 2005). The encrusted variety of the sinistral coiled $N$. pachyderma has its first frequent occurrence at $1.8 \mathrm{Ma}$ in the North Atlantic and the Norwegian Sea (Weaver \& Clement, 1986; Spiegler \& Jansen, 1989).

\section{Sr isotope stratigraphy}

Well 35/2-1 was only sampled with ditch-cutting samples. 133 / 8" $(34 \mathrm{~cm})$ casing was put in place at $539 \mathrm{~m}$. From that level to the base $(713 \mathrm{~m})$ the well was drilled with a $121 / 4^{\prime \prime}(31 \mathrm{~cm})$ drill bit, and the well was open during drilling. Since the deposits largely consist of loose, unconsolidated sediments, a significant element of caved sediments must be expected in the ditch-cutting samples. This comes in addition to error sources which may be introduced by reworked fossil tests and a relatively gentle slope on the part of the Sr curve for ages between $1.05 \mathrm{Ma}$ and recent (Fig. 2). Four samples from the reservoir section of the well were analysed for ${ }^{87} \mathrm{Sr} /{ }^{86} \mathrm{Sr}$ ratios. The samples were analysed twice for control purposes (Table 8; Fig. 9). The sample from $564 \mathrm{~m}$ gave ages close to recent. This indicates that the foraminiferal tests have been caved from the uppermost part of the well even though the 133 / $8^{\prime \prime}$ casing was put in place at $539 \mathrm{~m}$. The sample at $582 \mathrm{~m}$ gave $0.43 \mathrm{Ma}$ (based on the look-up table of Howarth \& McArthur (1997)) and 0.45 Ma (based on the look-up table of Howarth \& McArthur (2004)), respectively. A second analysis of the sample from $582 \mathrm{~m}$ gave $1.5 \mathrm{Ma}$ (based on the look-up table of Howarth \& McArthur (1997)) and 1.55 Ma (based on the look-up table of Howarth \& McArthur (2004)), respectively. By comparing with the biostratigraphic data, the second analysis indicates that the mollusc fragment was reworked. The sample at $591 \mathrm{~m}$ gave $1.7 \mathrm{Ma}$ based on both look-up tables. Comparing with the biostratigraphic data, this analysis was also probably based on a reworked mollusc fragment. A second analysis of the sample from $591 \mathrm{~m}$ gave an ${ }^{87} \mathrm{Sr} /{ }^{86} \mathrm{Sr}$ ratio which is not in the $\mathrm{Sr}$ look-up tables and is probably an error. The sample at $600 \mathrm{~m}$ gave $0.71 \mathrm{Ma}$ (based on the look-up table of Howard \& McArthur (1997)) and 0.73 Ma (based on the look-up table of Howarth \& McArthur (2004)). A second analysis of the sample at $600 \mathrm{~m}$ gave $0.15 \mathrm{Ma}$ (based on the look-up table of Howarth \& McArthur (1997)) and 0.21 Ma (based on the look-up table of Howarth \& McArthur (2004)). By comparing with the biostratigraphic data, the second analysis indicates that the mollusc fragments were caved (Table 8).

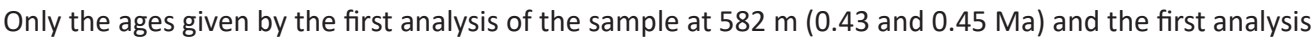
of the sample at $600 \mathrm{~m}(0.71$ and $0.73 \mathrm{Ma}$ ) are partially consistent with the biostratigraphic data.

\section{Seismic stratigraphy and correlation to the Sr samples}

The Peon gas field is located in the outer part of the Norwegian Channel in the northern North Sea. Here, a thick unit of prograding clinoforms has been deposited. These clinoforms were deposited during the early and middle Pleistocene. On top of these clinoforms a regional unconformity (URU) has been developed by erosion by the recurring Norwegian Channel Ice Stream (Fig. 10). Above the unconformity there is a package of flat-lying glacigenic sediments, either glacimarine, glacifluvial or tills. The Peon gas field is located in one of these flat-lying sandy units. Well 35/2-1 is located close to the eastern flank of the Quaternary basin (Fig. 1) but does not penetrate to the base Quaternary. The well penetrates the flat-lying units and in addition the uppermost prograding clinoforms (Fig. 10), here belonging to the seismically defined Naust $C$ unit of Ottesen et al. (2014). All the samples are from above the URU, and regional seismic considerations indicate that these sediments are of middle Pleistocene age.

\section{Geotechnical core Troll-8903}

Approximately $126 \mathrm{~km}$ south of well 35/2-1 the geotechnical borehole (core 8903; 60 $38.4^{\prime} \mathrm{N}, 03^{\circ}$ 43.4' E) was drilled in the Troll Field in the central part of the Norwegian Channel (Fig. 1). This borehole was cored continuously in the upper part and has a number of cores taken at varying intervals in the 
Table 8. Sr isotope data from well 35/2-1 (Peon). The samples were analysed at the University of Bergen. Sr ratios were corrected to NIST 987 = 0.710248. Numerical ages derived from the SIS look-up tables of Howarth \& McArthur (1997, 2004). NIST - National Institute for Standard and Technology.

\begin{tabular}{|c|c|c|c|c|c|}
\hline Litho. Unit & $\begin{array}{l}\text { Sample (ditch } \\
\text { cuttings) }\end{array}$ & Corrected ${ }^{87} /{ }^{86} \mathrm{Sr}$ & $2 \mathrm{~S}$ error & $\begin{array}{l}\text { Age (Ma; H\&M, 1997, } \\
2004 \text { mean values) }\end{array}$ & Analysed fossils \\
\hline Naust Fm & $564 \mathrm{~m}$ & 0.709178 & 0.000008 & Close to recent & Ca 60 tests of E. excavatum, Elphidium sp. (few). \\
\hline Naust Fm & $564 \mathrm{~m}$ & 0.709181 & 0.000008 & Close to recent & Ca 30 tests of E. excavatum, E. albiumbilicatum \\
\hline Naust Fm & $582 \mathrm{~m}$ & 0.709162 & 0.000009 & $0.427,0.446$ & Two mollusc fragments \\
\hline Naust Fm & $582 \mathrm{~m}$ & 0.709102 & 0.000006 & $1.504 ; 1.552$ & One mollusc fragment \\
\hline Naust Fm & $591 \mathrm{~m}$ & 0.707332 & 0.000009 & Not in the tables & One mollusc fragment \\
\hline Naust Fm & $591 \mathrm{~m}$ & 0.709093 & 0.000008 & $1.75,1.74$ & One mollusc fragment \\
\hline Naust Fm & $600 \mathrm{~m}$ & 0.709150 & 0.000009 & $0.711,0.729$ & One mollusc fragment \\
\hline Naust Fm & $600 \mathrm{~m}$ & 0.709170 & 0.000009 & $0.148,0.212$ & Three small mollusc fragments \\
\hline
\end{tabular}

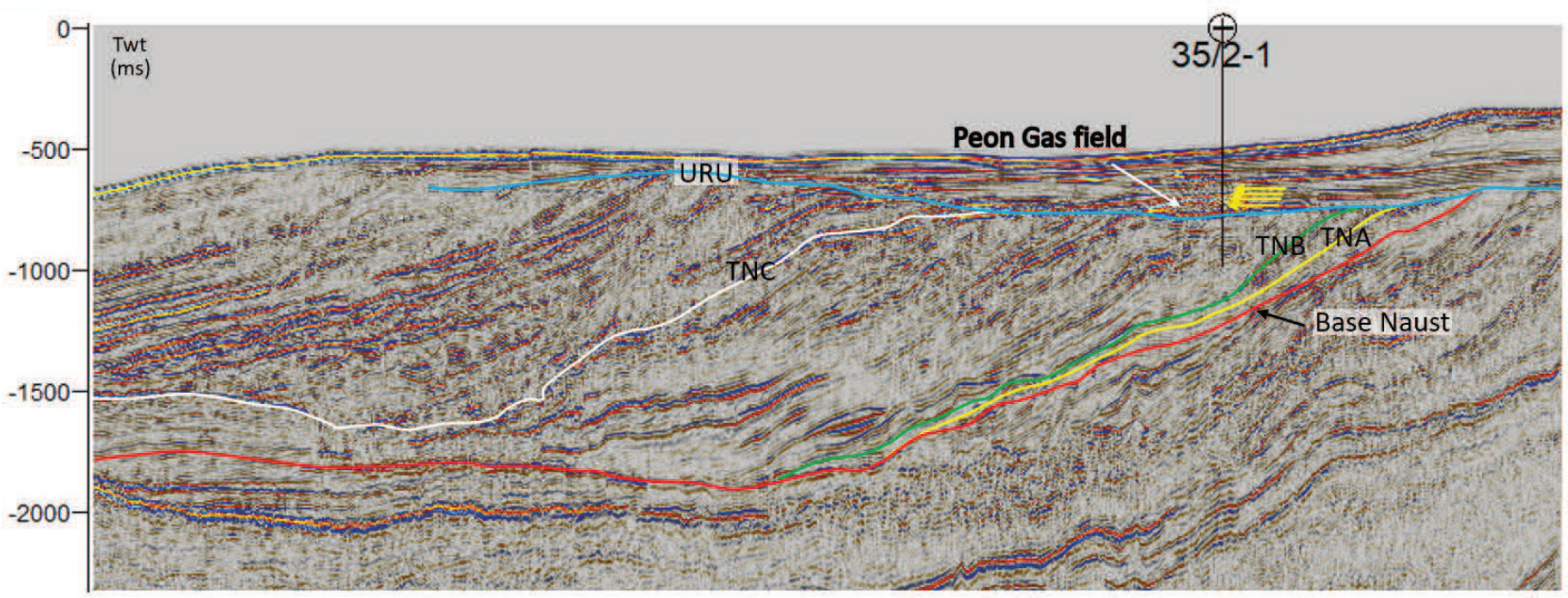

Figure 10. Seismic profile through well 35/2-1 (Peon gas field), northern North Sea, with interpreted Pleistocene seismic reflectors (from Ottesen et al., 2014) and levels for Sr sampling (yellow arrows). All samples for Sr analyses are from above the Upper Regional Unconformity (URU). TWT means two-way travel time. Location of the line is shown in Fig. 1.

lower part. Most of the approximately 200 m-thick Pleistocene sediment column was sampled, and the borehole penetrated down into the Oligocene (Sejrup et al., 1995). An extensive analytical programme, including sedimentological, geochronological and biostratigraphical techniques has been carried out on the cores. This includes palaeomagnetic investigations and amino-acid geochronology (Sejrup et al., 1995). This borehole is the only borehole on the Norwegian continental shelf that has a large core coverage in sediments from the middle to upper part of the Pleistocene.

Sejrup et al. (1995) recorded a glacigenic diamicton, named the Fedje diamicton (Lithozone L6), immediately above the base Pleistocene in the Troll area (URU), and the climatostratigraphic event corresponding to the glaciation during which this diamicton was deposited was designated the "Fedje Glaciation". According to Sejrup et al. (1995), these sediments are accurately dated since two normal 
polarity zones occurring within the assumed Matuyama Chron were recorded from Lithozone L6 and from the lower part of the overlying Lithozone L5, which was described as a marine pelite. It was suggested that these polarity zones represent the Jaramillo and Cobb Mountain events dated to between 0.98 and 1.07 and to $1.19 \mathrm{Ma}$, respectively, on the time scale of Berggren et al. (1995). Sejrup et al. (1995) correlated the Fedje Glaciation with the Menapian Glaciation in the Netherlands. Deposits from the Menapian Glaciation contain the oldest evidence of a major expansion of the Fennoscandian ice sheet in the form of rock fragments of Scandinavian origin (Zagwijn 1985, 1989). According to Lindner et al. (2004), the Menapian Glaciation is correlated with the Narevian Glaciation in Poland. From the central North Sea (Fladen area; British sector (borehole 81/26, see Fig. 1)), Sejrup et al. (1995) recorded a glacial event in a cored geotechnical borehole which is also correlated with these glaciations. In addition, the Vøring Plateau sediments document an increase in IRD at 1.2 to $1.1 \mathrm{Ma}$ (Jansen \& Sjøholm, 1991; Fronval \& Jansen, 1996). According to Sejrup et al. (1995), this suggests that the Fedje Glaciation was a regional event with a magnitude similar to the Weichselian maximum in this region. If there is not a large local erosion in the 35/2-1-area, it is likely that the ice stream which deposited the Fedje diamicton on the Troll Field is the same as the one which led to the deposition of the sandy glacimarine depositional system in the 35/2-1 area (Eidvin, 2005).

Sejrup et al. (1995) interpreted the seismic stratigraphy in the area of the borehole. They stated that the pelites of Lithozone 5 (their seismic unit C) have a characteristic strongly laminated seismic signature and a typical thickness of 50-60 ms. They also noted that this seismic unit has a large distribution in the Norwegian Channel. A geosection shows that the unit was deposited in a trough and appears to onlap the margins of the trough. Semic interpretation of $3 D$ data performed at the NPD confirms these observations. Seismic unit $\mathrm{C}$ can be correlated in the Norwegian Channel between the Troll Field and well 35/2-1 without much change in seismic character. Based on seismic and log data, the unit is tentatively correlated to the interval 532-552 m measured depth in 35/2-1, where it contributes to the caprock for the gas accumulation in the Peon discovery. It should be noted that the Lithozone $L 5$ in 35/2-1 is significantly thinner than in the Troll borehole and that the paleomagnetic results in that borehole came from the lower part of the zone. Consequently, if the interpretation of Sejrup et al. (1995) is correct, their results could be considered to represent a maximum age for Lithozone 5 in well 35/2-1.

Løseth \& Nygård (2019) have interpreted a regional three-dimensional (3 D) broadband seismic cube covering $35410 \mathrm{~km}^{2}$ of the northern North Sea between $60^{\circ}$ and $62^{\circ} \mathrm{N}$. They found that the sediments above URU at the base of the Norwegian Channel (till unit D) are present throughout most of the Norwegian Channel in the area they have investigated. They also found that the unit lies above the lower part of the North Sea Fan, the base of which has been interpreted to $0.5 \mathrm{Ma}$ based on regional considerations (Nygård et al., 2005). Sejrup et al. (1995) correlated seismic till unit D with Lithozone L6 in core 8903 in the Troll Field which they gave an age of ca. $1.1 \mathrm{Ma}$. Consequently, there is a mismatch between Løseth \& Nygård (2019) and the previously published Quaternary geological history of the northern North Sea when it comes to the dating of Quaternary events. Løseth \& Nygård (2019) considered that their suggested younger age gives a major shift in timing of the Quaternary geological events, implying that the age of the Peon reservoir sand is younger than previously suggested, and that the formation of the Norwegian Channel started much later (approximately at $0.5 \mathrm{Ma}$ ) than previously suggested.

Chauhan et al. (2019) have investigated samples from the Troll core 8903 by means of Sr isotope stratigraphy. Two samples from Lithozone $\mathrm{L} 6$ gave approximately 0.6 and $0.9 \mathrm{Ma}$. This is not very different from the ages we obtained from two of the samples from the reservoir section in well 35/3-1 (0.43-0.45 and 0.71-0.73 Ma, Table 8). However, in our opinion, the $\mathrm{Sr}$ data in general do not provide clear support for either of the ages given by Sejrup et al. (1995) or by Løseth \& Nygård (2019), respectively. A more precise dating may be obtained by performing a larger number of $\mathrm{Sr}$ analyses, based on foraminiferal tests from the lower part of Lithozone L5 and Lithozone L6 in core 8903 (Chauhan et al., 2019). However, it is our experience that $\mathrm{Sr}$ isotope stratigraphy often does not give a better stratigraphic resolution than \pm 0.5 million years even for Oligocene and Miocene samples, where the Cenozoic Sr curve has higher gradients of change in isotope ratios. The Oligocene period lasted 10.9 million years and the Miocene period lasted 17.7 million years, both considerably longer than the 2.6 million years of the Pleistocene. A stratigraphic resolution of $\pm 0.5 \mathrm{My}$ is usually sufficient in the Oligocene and Miocene, and significantly better than what biostratigraphic correlation can provide. 


\section{Area 4; well 6507/5-J-1 H from the the Skarv Field (Revfallet Fault Complex, Norwegian Sea shelf)}

In the production well $6507 / 5-\mathrm{J}-1 \mathrm{H}\left(65^{\circ} 44^{\prime} 17.17^{\prime \prime} \mathrm{N}, 07^{\circ} 39^{\prime} 04.83^{\prime \prime} \mathrm{E}\right.$, Fig. 1), Eidvin (2019) has investigated four samples for micropaleontology and lithology and two samples for $\mathrm{Sr}$ isotope ratios in a cored section in the lower part of the Naust Formation (1570 to $1613.3 \mathrm{~m}$; Fig. 11). The inclination of the well is $32^{\circ}$ at $1570 \mathrm{~m}$ and $32.5^{\circ}$ at $1613 \mathrm{~m}$ (Eidvin, 2019). The samples were taken at 1572.10, 1584.80, $1590 \mathrm{~m}$ and $1610.10 \mathrm{~m}$. Sr isotopes were analysed in the shallowest and deepest samples (1572.10 and $1610.10 \mathrm{~m})$.

\section{WELL 6507/5-J-1H}

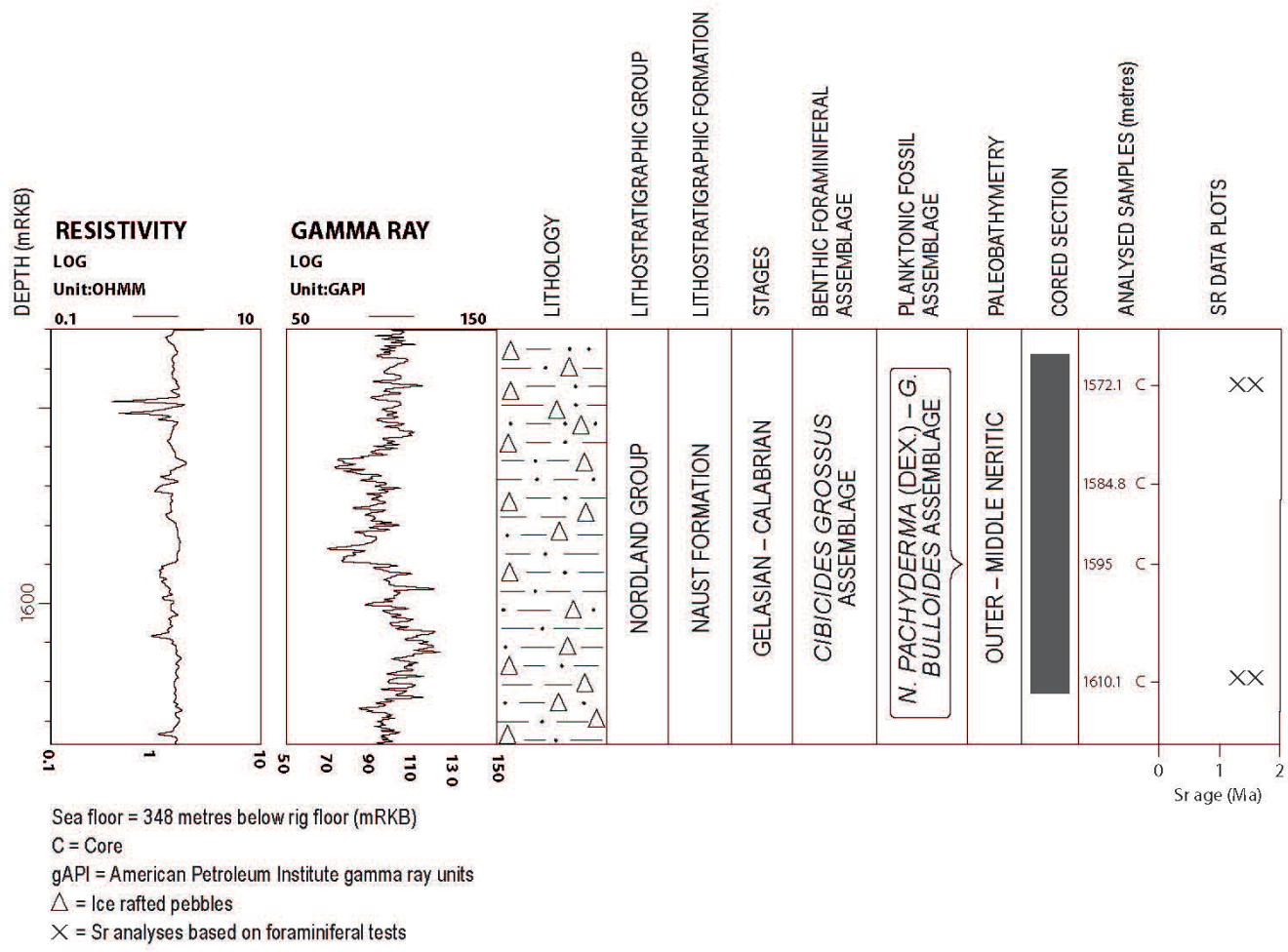

Figure 11. Well summary figure including resistivity and gamma-ray logs, lithology, lithostratigraphic units, stages, benthic foraminiferal assemblages, planktonic foraminiferal assemblages, paleobathymetry, cored section, analysed samples and Sr data plots for well 6507/5-J-1 H (according to Table 9). The plots are based on the ages obtained from the look-up table of Howarth \& McArthur (1997) and show mean values. The inclination of the well is $32^{\circ}$ at $1570 \mathrm{~m}$ and $32.5^{\circ}$ at $1613 \mathrm{~m}$ (modified after Eidvin (2019)).

\section{Lithology}

1610.10 to $1572.10 \mathrm{~m}$ (Naust Formation)

The core samples contain a mixture of clay, silt, sand and pebbles of crystalline rocks typical for glacial diamictons. Sand and pebbles are most common in the uppermost and in the lowermost sample (Fig. 11; Eidvin, 2019). Core photos are available at the NPD fact-pages (npd.no/facts).

In the samples at 1572.10 and $1610.10 \mathrm{~m}$, we recorded a benthic foraminiferal Cibicides grossus assemblage (Fig. 11). The assemblage also includes Elphidium excavatum, Elphidium albiumbilicatum, Cassidulina teretis and Nonion affine. We did not record any planktonic foraminifera in these samples. 
The sample at $1584.80 \mathrm{~m}$ is completely barren of foraminifera. The sample at $1595 \mathrm{~m}$ does not contain any C. grossus, but includes Elphidium excavatum, Elphidium albiumbilicatum, Cassidulina teretis and Nonion affine. The sample also contains planktonic foraminifera including Globigerina bulloides (rare) and Neogloboquadrina pachyderma (dextral; common). The $C$. grossus assemblage correlates with Zone NSB 15 of King (1989; North Sea) which is of Gelasian to early Calabrian age. G. bulloides is common in deep-sea boreholes from the North Atlantic and the Norwegian Sea in sediments from approximately 2.4 to $2.2 \mathrm{Ma}$ and in sediments deposited during warm periods in the Pleistocene (Kellogg, 1977). N. pachyderma (dextral) is common in similar boreholes from the same areas in sediments from approximately 1.9 to $1.8 \mathrm{Ma}$ (Weaver \& Clement, 1987; Spiegler \& Jansen, 1989) and during warm periods in younger parts of the Pleistocene (Eidvin, 2019).

\section{Sr isotope stratigraphy}

$\mathrm{Sr}$ analyses of two samples based on benthic foraminiferal tests have been carried out on the cored section in well 6507/5-J-1 H. The sample from $1610.1 \mathrm{~m}$ gave 1.4 Ma (based on the look-up table of Howarth \& McArthur (1997)) and 1.5 Ma (based on Howarth \& McArthur (2004)), respectively. A second analysis of the sample from $1610.1 \mathrm{~m}$ gave $1.7 \mathrm{Ma}$ based on both look-up tables. The sample from $1572.10 \mathrm{~m}$ gave 1.3 Ma on both look-up tables, and a second analysis from $1572.10 \mathrm{~m}$ gave $1.5 \mathrm{Ma}$ based on Howarth \& McArthur (1997) and 1.6 based on Howard \& McArthur (2004; Table 9; Fig. 11), respectively. ${ }^{87} \mathrm{Sr} /{ }^{86} \mathrm{Sr}$ isotopic compositions which give ages between 1.6 and 1.0 Ma plot on the steepest part of the $\mathrm{Sr}$ isotope curve for the Pleistocene and consequently, theoretically, should provide the most reliable Pleistocene ages (Eidvin, 2019).

Table 9. Sr isotope data from well 6507/5-J-I H. The samples were analysed at the University of Bergen. Sr ratios were corrected to NIST 987 = 0.710248. Numerical ages derived from the SIS look-up tables of Howarth \& MCArthur (1997, 2004). NIST - National Institute for Standard and Technology.

\begin{tabular}{llllll}
\hline Litho. Unit & Sample (core) & Corrected 87/86Sr & 2S error & $\begin{array}{l}\text { Age (Ma; H\&M, 1997, } \\
\text { 2004 mean values) }\end{array}$ & Analysed fossil species \\
\hline Naust Fm & $1572.10 \mathrm{~m}$ & 0.709116 & 0.00007 & $1.312,1.324$ & Approximately 30 tests of $C$. teretis \\
Naust Fm & $1572.10 \mathrm{~m}$ & 0.709100 & 0.00009 & $1.546,1.591$ & Approximately 30 tests of $C$. teretis \\
Naust Fm & $1610.10 \mathrm{~m}$ & 0.709107 & 0.00009 & $1.423,1.461$ & Approximately 30 tests of $C$. teretis \\
Naust Fm & $1610.10 \mathrm{~m}$ & 0.709096 & 0.00009 & $1.657,1.672$ & Approximately 30 tests of $C$. teretis \\
\hline
\end{tabular}

\section{Seismic stratigraphy and correlation to the $\mathrm{Sr}$ samples}

Area 4 is located on the outer Norwegian Sea shelf east of the Skjoldryggen area. The Pleistocene deposits comprise a series of prograding units, cut by a marked erosional unconformity with a series of flat-lying glacigenic units above (Figs. 1 \& 12). Ottesen et al. (2009) subdivided these units into a series of Naust units, named with a letter for each unit $(N, A, U, S, T)$, the oldest $N$, and the youngest $T$. Well 6507/5-J-1 H penetrates the two oldest Naust units, Naust N and A and the youngest (Naust T). The samples for the $\mathrm{Sr}$ dating are taken in the youngest part of the oldest Naust $\mathrm{N}$ unit (Fig. 12). Ottesen et al. (2009) suggested an age between approximately 1.5 and 2.7 Ma for the oldest Naust unit $\mathrm{N}$ based on regional considerations.

Prior to drilling, the cored section in 6507/5-J-1 H was predicted to belong to the upper Miocene Kai Formation. The consequence of the redating is shown in a geosection in Fig. 13. In Fig. 13, the lower Pleistocene unit P1 in the area west of the $\$ \varnothing r$ High was previously considered to be Miocene. In order to verify the new Miocene-Pleistocene boundary, results from 6507/5-J-1 H were correlated with the exploration well 6507/5-1, which is located about $1 \mathrm{~km}$ away. Ditch cuttings from 6507/5-1 were sampled and analysed for the Miocene and Oligocene stratigraphy (see also Eidvin (2019). 


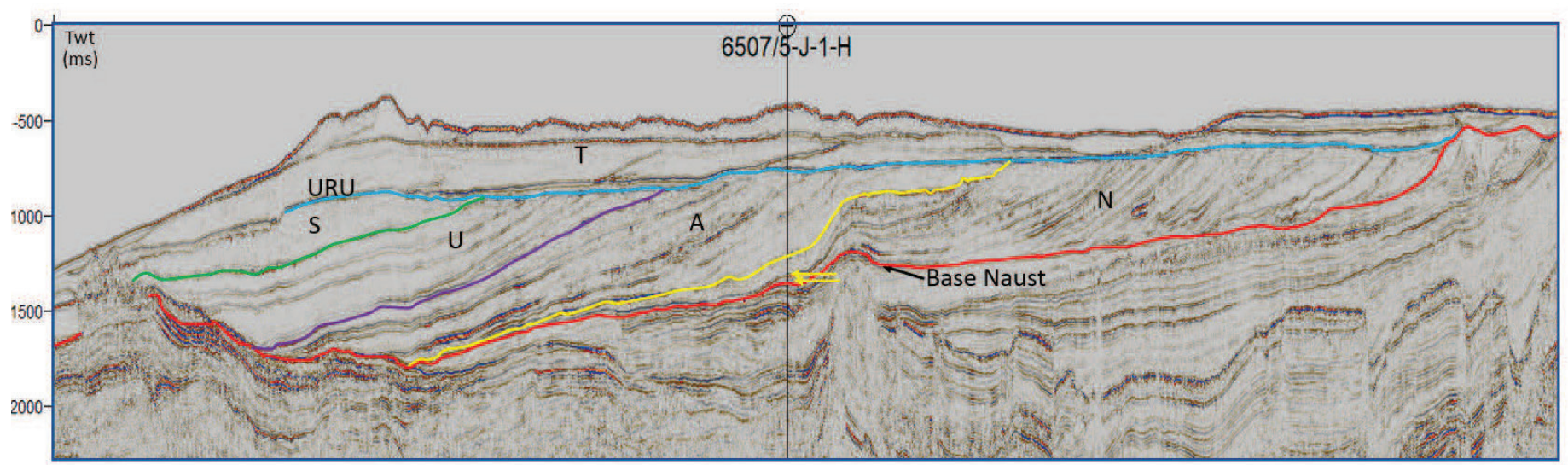

Figure 12. Seismic profile through well 6507/5-J-1 H (Skarv field) on the Norwegian Sea shelf with interpreted Pleistocene seismic reflectors (from Ottesen et al., 2009) and the levels for Sr sampling (yellow arrows). All samples for Sr analyses are located within the oldest Naust unit (Naust $N$ with a suggested age between approximately 2.6 and $1.5 \mathrm{Ma}$ ). TWT means two-way travel time. Location of the line is shown in Fig. 1.

A)

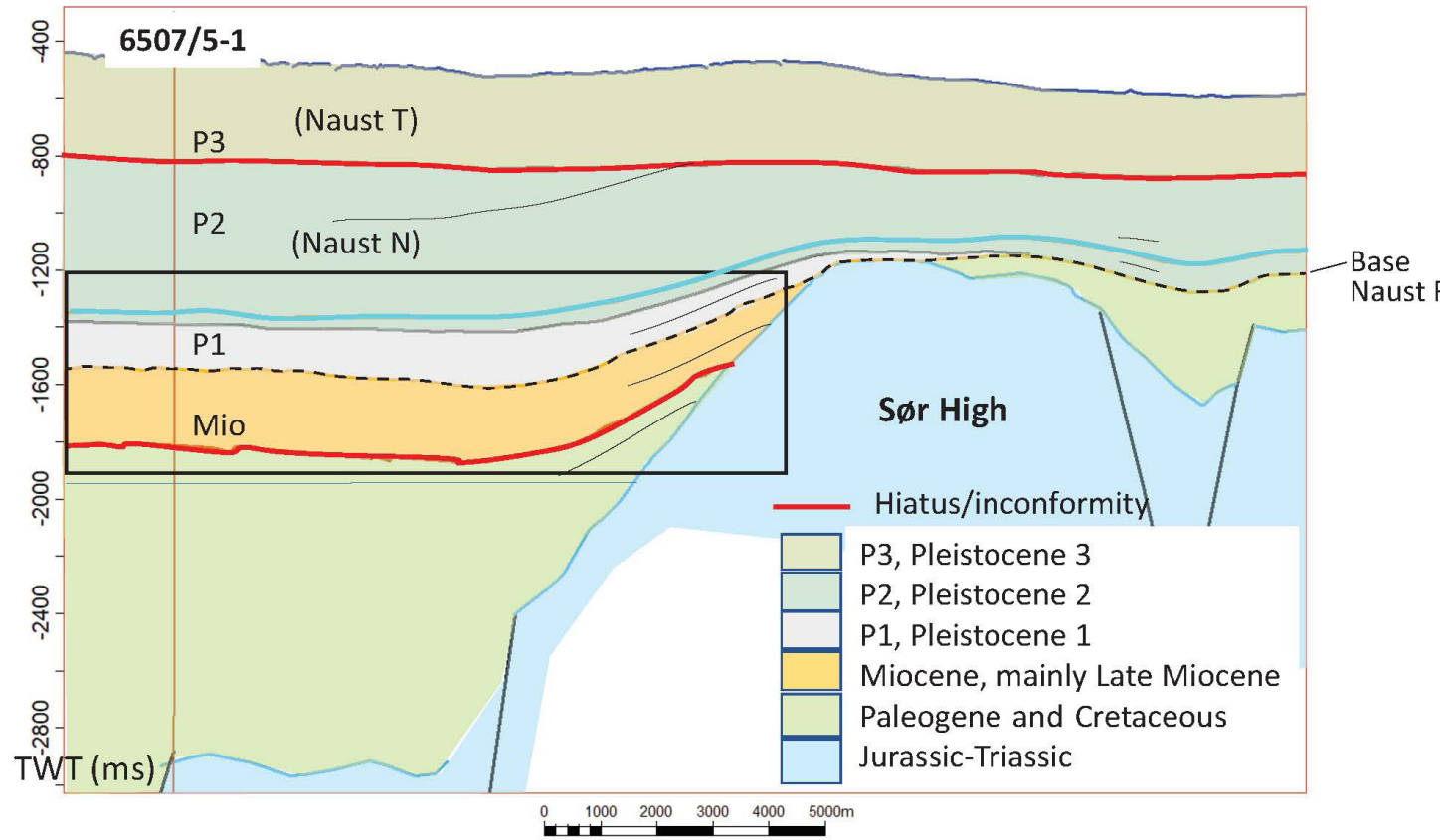

B)

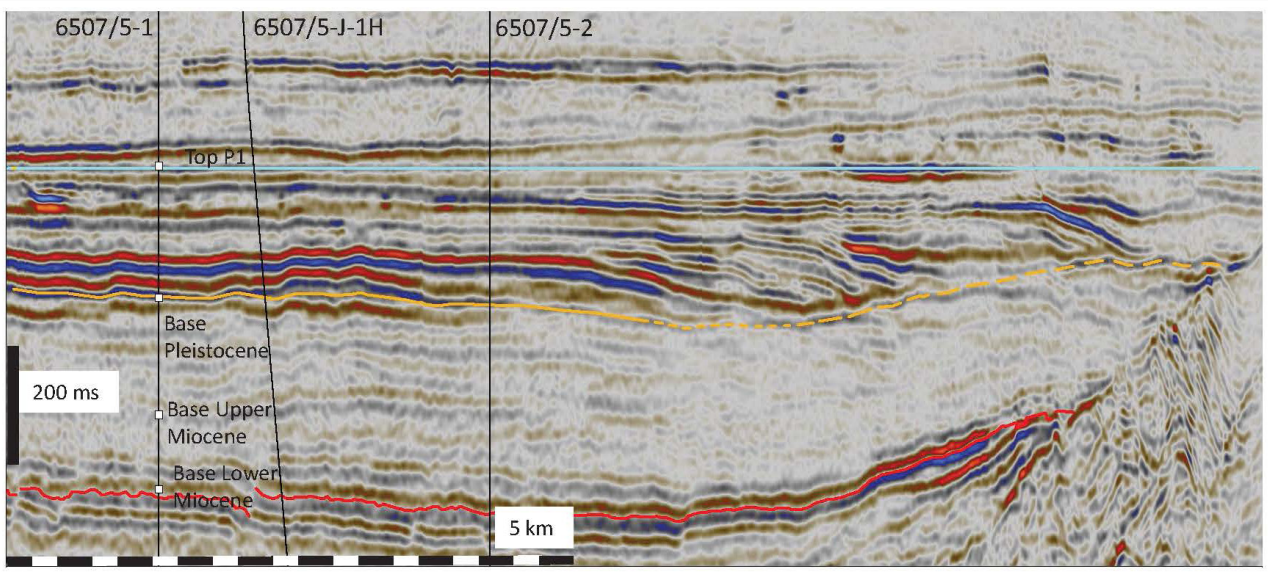

Figure 13. A) East-west geoseismic section and seismic profile in two-way travel time (TWT: in ms) from Dønna Terrace to the Sør High. Pleistocene 1 (previously interpreted as upper Miocene in operator of PL 212's completion log (see Eidvin (2019)) has a seismic expression typical for contourites. Pleistocene 2 exhibits low-angle clinoforms prograding to the west. Pleistocene 3 was deposited under glacial condition on top of the upper regional unconformity (URU). B) The box shows the location of the seismic section. Seismic data are courtesy of Skarv PL. 212 (after Riis \& Wolff (2020)). Location of the line is shown in Fig. 1. 
The $\$ \varnothing r$ High is a local culmination of the Nordland Ridge which has been tectonically uplifted in several phases since the Mesozoic, including in the Pleistocene (Riis \& Wolff, 2020). The studied well was drilled in a basinal setting flanking the uplifted high. Within this basin, both the studied section P1 and the underlying upper Miocene Kai Formation contain conspicuous trough-like structures suggesting deposition by contouritic currents adjacent to the high (Løseth \& Henriksen, 2005). The seismic section line (Fig. 13) was flattened at the blue horizon in order to remove most effects of the tectonic dip. The blue horizon corresponds to the base of the regionally prograding clinoforms of the Naust Formation. The setting here is particularly interesting for age dating, because dating can be used not only for stratigraphy but also to constrain recent tectonic events.

\section{Discussion}

Reinardy et al. (2017a, b) have investigated ditch-cutting samples from the middle and lower parts of the Pleistocene succession and the upper part of a unit they assumed to belong to the Utsira Formation in the exploration well 16/1-8. Well 16/1-8 is located approximately $5 \mathrm{~km}$ southwest of well $16 / 1-4$ (Fig. 1). They analysed 17 samples from 594 metres below the sea floor (mbsf) to 264 mbsf which are $727 \mathrm{~m}$ to $397 \mathrm{~m}$ measured from the rig floor (mRKB). They defined the top of the Utsira Formation to be at about $717 \mathrm{mRKB}$. They analysed each sample for ${ }^{87} \mathrm{Sr} /{ }^{86} \mathrm{Sr}$ ratios just once and consequently, did not perform any additional analyses for control purposes.

When drilling well $16 / 1-8,20^{\prime \prime}$, casing was put in place when the drill bit was at 393.5 mRKB, and $133 / 8^{\prime \prime}$ casing was put in place when the drill bit reached 1187 mRKB. During the drilling between these depths the borehole was open, exposed to the rotating drill string and to circulating drill mud. That includes the entire section investigated by Reinardy et al. (2017a). The unconsolidated sediments were probably continuously dislodged throughout the section and may have been incorporated into the drill-cutting samples. However, Reinardy et al. (2017a) have not discussed sources of error using foraminiferal tests from ditch cuttings for Sr analyses.

Reinardy et al. (2017a) used the benthic foraminiferal species Elphidium excavatum and Cassidulina laevigata for $\mathrm{Sr}$ analysis. These species have a stratigraphic range comprising the entire Pleistocene. The range of $C$. laevigata also includes the Pliocene and Miocene. They did not analyse any foraminiferal species with short ranges which would have been beneficial when analysing ditch cuttings that may be contaminated with caved material. There are not many such species in Pleistocene deposits, but there are some. When analysing foraminiferal tests from ditch cuttings from Cenozoic successions, it is common practice to use species with short stratigraphic ranges (index fossils). It is essential to pick the tests from, or close to, the highest common occurrence in an attempt to minimise the content of caved tests (Eidvin \& Rundberg, 2007). The samples analysed by Reinardy et al. (2017a) gave ages of $1.3 \mathrm{Ma}$ in the upper part of the Pleistocene succession, 2.3 Ma in the lower part and 2.4 and 2.2 Ma in the unit they assumed belongs to the Utsira Formation. In well 16/1-4 we recorded ages of 5.9-5.8 Ma and 4.2-4.1 Ma from the uppermost part of the Utsira Formation. However, according to the NPD fact-pages (npd. no/facts) including the completion log for well 16/1-8, the top of the Utsira Formation is at 745 mRKB. This means that Reinardy et al. (2017a) have only investigated the Pleistocene Naust Formation. Some of the $\mathrm{Sr}$ data they obtained from the Pleistocene succession showed some examples with older above younger ages, just like those we recorded from well 16/1-4. However, also as we recorded from well $16 / 1-4$, there is a general trend with increasing ages with increasing depths. We assume that Reinardy et al. (2017a) have been very fortunate that they did not encounter more caved fossil tests which may have ruined this trend. We find it quite strange that the general trend with increasing ages is quite similar to the trend in well 16/1-4 since the samples in 16/1-8 consist of ditch cuttings, which usually have some contamination with caved sediments, whereas the samples in well 16/1-4 consist of sidewall cores which are not or very seldom contaminated with caved material. If Reinardy et al. (2017a) had analysed each sample two or three times for control purposes, as we did with well 16/1-4, a greater spread of results may have appeared.

In the Netherlands too, the use of the Sr isotope stratigraphy to date the Pleistocene has not been without problems. Wesselingh et al. (2005) discussed a discrepancy between ages mainly based on $\mathrm{Sr}$ isotope stratigraphy by Jansen et al. $(2004 a, b)$ and ages mainly based on paleontological evidence, from multiple sources, for the Pleistocene Maassluis Formation in the western Netherlands. The discrepancies are up to a few million years. 


\section{Conclusions}

In the current study, we performed Sr isotope analyses on samples from the Pleistocene succession in four areas on the Norwegian continental shelf. A total of 37 samples from conventional cores, sidewall cores as well as ditch cuttings, and from both exploration and production wells, were analysed. Each sample was analysed several times for control purposes. Altogether 99 analyses were performed on the samples. The obtained Sr data were compared with previously published biostratigraphic, lithostratigraphic and seismic data and with new micropaleontological and palynological data.

In wells 34/8-9 S, 34/8-A-1 H and 34/8-A-33 H from the Visund Field (Tampen, northern North Sea; designated area 1), we have investigated short cored sections in the basal part of the Naust Formation. The obtained ${ }^{87} \mathrm{Sr} /{ }^{86} \mathrm{Sr}$ ratios gave ages that varied between 6.3 and $1.8 \mathrm{Ma}$. We assume that the large variations in the estimated ages, also within the same samples, for a significant part are due to the uncertainty in calculation of ages from the flat, latest Pliocene to earliest Pleistocene part of the $\mathrm{Sr}$ curve. An additional factor may be that some of the analysed foraminifera and mollusc tests may have been reworked from upper Miocene and lower Pliocene deposits, since the sediments consist mainly of contourite deposits and are allochthonous sediments. The palynological analyses support this interpretation as all the samples contain reworked palynomorphs. Consequently, the large variations in estimated ages can be due to both the uncertainty in calculation of ages from a flat $\mathrm{Sr}$ curve and to reworked calcareous fossil tests. The presumed in situ dinocyst assemblages suggest an age between 2.6 and $1.4 \mathrm{Ma}$ for these cores.

In well 16/1-4 from the southern Viking Graben in the northern North Sea (designated area 2), we investigated 14 sidewall core samples from the upper part of the lower Pliocene to the middle Pleistocene by means of Sr isotope stratigraphy. Two of the samples are from the uppermost part of the Utsira Formation and twelve samples are from the lower and middle part of the Naust Formation. The samples from the Utsira Formation gave 5.9 and $5.8 \mathrm{Ma}(768.5 \mathrm{~m})$ and 4.2 and $4.1 \mathrm{Ma}(767.5 \mathrm{~m})$, repectively. The ${ }^{87} \mathrm{Sr} /{ }^{86} \mathrm{Sr}$ ratios obtained from all the Naust Formation samples, from 765.5 to 357.5 $\mathrm{m}$, plot on most parts of the $\mathrm{Sr}$ isotope curve for the Pleistocene. The obtained ages gave a quite large spread with older above younger ages in some cases. There are also some variations in ages within the same samples. The ages range from 5.0 to $1.1 \mathrm{Ma}$ and show a tendency of increasing age with increasing depth, but not a clear tendency. However, most samples in the lower part of the Naust Formation gave ages of approximately 2.4 to $2.1 \mathrm{Ma}$ and most samples in the upper part of the Naust Formation gave ages of 1.3 to $1.0 \mathrm{Ma}$.

The Peon gas discovery was proven in the exploration well 35/2-1 in the Tampen area in the northern North Sea (designated area 3) in a sandy glacimarine depositional system at about 574 mRKB. The depositional system is situated directly above the angular mid Pleistocene unconformity (URU). The well was drilled from 384 to $713 \mathrm{~m}$ in the northern part of the Norwegian Channel, and was interpreted to penetrate a succession of delta-like sediments deposited by subglacial rivers in the area where the north-flowing ice stream met deep water in the Norwegian Sea. Four samples from the reservoir section of the well were analysed for ${ }^{87} \mathrm{Sr} /{ }^{86} \mathrm{Sr}$ ratios. The samples were analysed twice for control purposes. The sample from $564 \mathrm{~m}$ gave ages close to recent. This indicates that the foraminiferal tests have been caved from the uppermost part of the well even though the $133 / 8^{\prime \prime}$ casing was put in place at $539 \mathrm{~m}$. The sample at $582 \mathrm{~m}$ gave ages of 0.43 and $0.45 \mathrm{Ma}$, respectively. A second analysis of the sample from $582 \mathrm{~m}$ gave 1.5 and $1.55 \mathrm{Ma}$. By comparing with the biostratigraphic data, the second analysis must be interpreted as indicating that the analysed mollusc fragment was reworked. The sample at $591 \mathrm{~m}$ gave an age of $1.7 \mathrm{Ma}$, and this analysis was also probably based on a reworked mollusc fragment. A second analysis of the sample from $591 \mathrm{~m}$ gave an ${ }^{87} \mathrm{Sr} /{ }^{86} \mathrm{Sr}$ ratio which is not in the $\mathrm{Sr}$ look-up tables and is probably an error. The sample at $600 \mathrm{~m}$ gave 0.71 and $0.73 \mathrm{Ma}$. A second analysis of the sample at 600 $\mathrm{m}$ gave 0.15 and $0.21 \mathrm{Ma}$. By comparing with the biostratigraphic data, the second analysis indicates that the mollusc fragments were caved. Only the ages given by the first analysis of the sample at $582 \mathrm{~m}(0.43$ and $0.45 \mathrm{Ma})$ and the first analysis of the sample at $600 \mathrm{~m}(0.71$ and $0.73 \mathrm{Ma})$ are partially consistent with the biostratigraphic data.

In a cored section in the production well 6507/5-J-1 H from the Skarv Field (Revfallet Fault Complex; designated area 4), $\mathrm{Sr}$ analyses of two samples based on benthic foraminiferal tests have been carried out. The sample from $1610.1 \mathrm{~m}$ gave 1.4 and $1.5 \mathrm{Ma}$. A second analysis of the sample from $1610.1 \mathrm{~m}$ 
gave 1.7 Ma. The sample from $1572.10 \mathrm{~m}$ gave 1.3 and $1.5 \mathrm{Ma}$. A second analysis from $1572.10 \mathrm{~m}$ gave 1.5 and $1.6 \mathrm{Ma} .{ }^{87} \mathrm{Sr} /{ }^{86} \mathrm{Sr}$ isotopic compositions which give ages between 1.6 and $1.0 \mathrm{Ma}$ plot on the steepest part of the $\mathrm{Sr}$ isotope curve for the Pleistocene and consequently, theoretically, should provide the most reliable Pleistocene ages.

Acknowledgements. The authors are grateful to Rune Goa (NPD) for drawing the figures, Tone Tjelta Hansen (NPD) for preparing the foraminiferal samples, Anette Ryge (GEUS) and Charlotte Olson (GEUS) for preparing the palynology samples, David Roberts (Geological Survey of Norway (NGU)) for improving the language, Yuval Ronen (University of Bergen) for executing the Sr isotope analyses, Morten Smelror (NGU) for constructive comments and Joya Tetreault (NGU) for her help with producing the seismic sections. We acknowledge Christine Batchelor (University of Cambridge) and Jan Sverre Laberg (University of Tromsø) for their very constructive reviews and the NPD for permission to publish the manuscript. Thanks also to Teena Chauhan (University of Bergen) for discussions.

\section{References}

Batchelor, C.L., Ottesen, D. \& Dowdeswell, J.A. 2017: Quaternary evolution on the northern North Sea margin through glacigenic debris-flow and contourite deposition. Journal of Quaternary Science 32, 416-426. https://doi.org/10.1002/jqs.2934.

Batten, D.J. \& Koppelhus, E.B. 1996: Chapter 20D. Biostratigraphic significance of uppermost Triassic and Jurassic miospores in Northwest Europe. In: Jansonius, J. \& McGregor, D.C. (eds.): Palynology: principles and applications, American Association of Stratigraphic Palynologists Foundation, pp. 795-806.

Berggren, W.A., Kent, D.V, Swisher, C.C. III \& Aubry, M.-P. 1995: A Revised Cenozoic Geochronology and Chronostratigraphy. In: Berggren, W.A. et al. (eds.): Geochronology Time Scale and Global Stratigraphic Correlation, Society for Sedimentary Geology Special Publication 54, pp. 129-212.

https://doi.org/10.2110/pec.95.04.0129.

Bujak, J. \& Mudge, D. 1994: A high-resolution North Sea Eocene dinocyst zonation. Journal of the Geological Society, London 151, 449-462. https://doi.org/10.1144/gsjgs.151.3.0449.

Carstens, H. 2005: Fra problem - til mulighet. Geo 7, 26-30.

Chauhan, T., Sejrup, H.P., Hjelstuen, B.O., Kaufman, D. \& Baig, I. 2019: Quaternary geochronology of the North Sea - preliminary results from Troll and Fladen region. NGF Abstract \& Proceedings, Number 1. https://reqube.w.uib.no/files/2019/03/A0-Poster_winter-meeting.pdf.

Cohen, K.M., Finney, S.C., Gibbard, P.L. \& Fan, J.-X. 2013: The ICS International Chronostratigraphic Chart. Updated in 2018. Episodes 36, 199-204. https://doi.org/10.18814/epiiugs/2013/v36i3/002.

Dahlgren, K.I.T., Vorren, T.O., Stoker, M.S., Nielsen, T., Nygård, A. \& Sejrup, H.P. 2005: Late Cenozoic prograding wedges on the NW European continental margin: their formation and relationship to tectonics and climate. Marine and Petroleum Geology 22, 1089-1110.

https://doi.org/10.1016/j.marpetgeo.2004.12.008.

De Schepper, S. \& Head, M. 2009: Pliocene and Pleistocene dinoflagellate cyst and acritarch zonation of DSDP Hole 610A, eastern North Atlantic. Palynology 33, 179-218.

https://doi.org/10.2113/gspalynol.33.1.179.

De Verteuil, L. \& Norris, G. 1996: Miocene dinoflagellate stratigraphy and systematics of Maryland and Virginia. Micropaleontology 42, 1-172. https://doi.org/10.2307/1485926.

Dybkjær, K. 1988: Palynological zonation and stratigraphy of the Jurassic section in the Gassum No. 1-borehole, Denmark. DGU Series A 21, 72 pp. 
Dybkjær, K. 2004: Morphological and abundance variations in Homotryblium-cyst assemblages related to depositional environments; uppermost Oligocene - Lower Miocene, Jylland, Denmark. Palaeogeography, Palaeoclimatology, Palaeoecology206,41-58.https://doi.org/10.1016/j.palaeo.2003.12.021.

Dybkjær, K. \& Piasecki, S. 2010: Neogene dinocyst zonation in the eastern North Sea Basin, Denmark. Review of Palaeobotany and Palynology 161, 1-29. https://doi.org/10.1016/j.revpalbo.2010.02.005.

Dybkjær, K., Rasmussen, E.S., Eidvin, T., Grøsfjeld, K., Riis, F., Piasecki, \& Śliwińska, K.K. 2020: A new stratigraphic framework for the Miocene - Lower Pliocene deposits offshore Scandinavia: A multiscale approach. Geological Journal. 2020, 1-27.

Egger, L.M., Sliwinska, K.K., van Peer, T.E., Liebrand, D., Lippert, P.C., Friedrich, O., Wilson, P.A., Norris, R.D. \& Pross, J. 2016: Magnetostratigraphically-calibrated dinoflagellate cyst bioevents for the uppermost Eocene to lowermost Miocene of the western North Atlantic (IODP Expedition 342, Paleogene Newfoundland sediment drifts). Review of Palaeobotany and Palynology 234, 159-185. https://doi.org/10.1016/j.revpalbo.2016.08.002.

Eidvin, T. 2005: Biostratigraphic investigation of well 35/2-1. https://www.npd.no/globalassets/1-npd/ publikasjoner/forskningsartikler/biostratigraphic__investigation_of_35_2_1.pdf.

Eidvin, T. 2019: Biostratigrafi and Strontium Isotope Stratigraphy (SIS) of the upper part of the Brygge Formation, Kai and Naust formations in well 6507/5-1 and cored section of the Naust Formation in well 6507/5-J-1 H from the Skarv Field (Revfallet Fault Complex, Norwegian Sea shelf). Updated in 2020. NPD stratigraphic report 2019/01. https://www.npd.no/globalassets/1-npd/publikasjoner/forskningsartikler/6507-5-1-og-6507-5-j-1-h-u-paleogene-and-neogene-stratigraphy-with-figures.pdf.

Eidvin, T. \& Rundberg, Y. 2001: Late Cainozoic stratigraphy of the Tampen area (Snorre and Visund fields) in the northern North Sea, with emphasis on the chronology of early Neogene sands. Norsk Geologisk Tidsskrift 81, 119-160.

Eidvin, T. \& Rundberg, Y. 2007: Post-Eocene strata of the southern Viking Graben, northern North Sea; intergrated biostratigraphic, Strontium isotopic and lithostratigraphic study. Norwegian Journal of Geology 87, 391-450.

Eidvin, T., Koç, N., Smelror, M. \& Jansen, E. 1998: Biostratigraphical investigations of borehole 6704/12GB1 from the Gjallar Ridge on the Vøring Plateau, Report for the Seabed Project. OD-98-22. https:// www.npd.no/globalassets/1-npd/publikasjoner/forskningsartikler/investigation_6704-12-gb1.pdf.

Eidvin, T., Jansen, E., Rundberg, Y., Brekke, H. \& Grogan, P. 2000: The upper Cainozoic of the Norwegian continental shelf correlated with the deep-sea record of the Norwegian Sea and North Atlantic. Marine and Petroleum Geology 17, 579-600. https://doi.org/10.1016/S0264-8172(00)00008-8.

Eidvin, T., Bugge, T. \& Smelror, M. 2007: The Molo Formation, deposited by coastal progradation on the inner Mid-Norwegian continental shelf, coeval with the Kai Formation to the west and the Utsira Formation in the North Sea. Norwegian Journal of Geology 87, 75-142.

Eidvin, T., Riis, F., Rasmussen, E.S. \& Rundberg, Y. 2013: Investigation of Oligocene to Lower Pliocene deposits in the Nordic area. NPD Bulletin No 10.

https://www.npd.no/engelsk/cwi/pbl/NPD_papers/Hyperlink-NPD-Bulletin-10.pdf.

Eidvin, T., Ullmann, C.V., Dybkjær, K., Rasmussen, E.S. \& Piasecki, S. 2014: Discrepancy between Sr isotope and biostratigraphic datings of the upper middle and upper Miocene successions (eastern North Sea Basin, Denmark). Palaeogeography, Palaeoclimatology, Palaeoecology 411, 267-280. https://doi.org/10.1016/j.palaeo.2014.07.005.

Eidvin, T., Riis, F. \& Smelror, M. In review: A revised lithostratigraphic scheme for the Cenozoic succession on the Norwegian continental shelf (NPD Bulletin 12). Norwegian Journal of Geology. 
Eldrett, J.S., Harding, I.C., Firth, J.V. \& Roberts, A.P. 2004: Magnetostratigraphic calibration of Eocene-Oligocene dinoflagellate cyst biostratigraphy from the Norwegian-Greenland Sea. Marine Geology 204, 91-127. https://doi.org/10.1016/S0025-3227(03)00357-8.

Fronval, T. \& Jansen, E. 1996: Late Neogene paleoclimates and paleoceanography in the IcelandNorwegian Sea: evidence from the Iceland and Vøring Plateaus. In: Thiede, J., Myhre, A.M., Firth, J.V., John, G.L. \& Ruddiman, W.F. (eds.): Proceedings of the Ocean Drilling Program, Scientific Results 151, College Station, TX (Ocean Drilling Program), pp. 455-468. https://doi.org/10.2973/odp.proc.sr.151.134.1996.

Gonthier, E., Faugeres, J.C. \& Stow, D.A.V. 1984: Contourite facies of the Faro Drift, Gulf of Cadiz. In: Stow, D.V.A. \& Piper, D.J.W. (eds.): Fine-grained sediments, deep-water processes and facies, Geological Society, London, Special Publications 15, pp. 275-291. https://doi.org/10.1144/GSL.SP.1984.015.01.18.

Gradstein, F., Ogg, J. \& Smith, A. 2004: A Geological Time Scale. Cambridge University Press, Cambridge, U. K.

Heilmann-Clausen, C. 1985: Dinoflagellate stratigraphy of the uppermost Danian to Ypresian in the Viborg-1 borehole, central Jylland, Denmark. Geological Survey of Denmark, A7, 69pp.

Heilmann-Clausen, C. 1987: Lower Cretaceous dinoflagellate biostratigraphy in the Danish Central Trough. Geological Survey of Denmark, A17, 89pp.

Heilmann-Clausen, C. \& Van Simaeys, S. 2005: Dinoflagellate cysts from the Middle Eocene to lowermost Oligocene succession in the Kysing research borehole, central Danish basin. Palynology 29, 143-204. https://doi.org/10.1080/01916122.2005.9989606.

Helland, P.E \& Holmes, M.A. 1997: Surface Textural Analysis of Quartz Sand Grains from ODP Site 918 Off the Southeast Coast of Greenland Suggests Glaciation of Southern Greenland at $11 \mathrm{Ma}$. Palaeogeography, Palaeclimatology, Palaeoecology 135, 109-121. https://doi.org/10.1016/S0031-0182(97)00025-4.

Howarth, R.J. \& McArthur, J.M. 1997: Statistics for Strontium Isotope Stratigraphy: A Robust LOWESS Fit to Marine Sr Isotope Curve for 0 to $206 \mathrm{Ma}$, with Look-up table for Derivation of Numeric Age. Journal of Geology 105, 441-456. https://doi.org/10.1086/515938.

Howarth, R.J. \& McArthur, J.M. 2004: Strontium Isotope Stratigraphy. In Gradstein, F.M. \& Ogg, J.G. (eds.): A Geological Time Scale, with Look-up Table Version 4: 08/04, Cambridge University Press, Cambridge, U.K., 96-105. https://doi.org/10.1017/СBO9780511536045.008.

Jansen, E. \& Sjøholm, J. 1991: Reconstruction of glaciation over the past 6 Myr from ice- borne deposits in the Norwegian Sea. Nature 349, 600-603. https://doi.org/10.1038/349600a0.

Jansen, H.S.M., Huizer, J., Dijkmans, J.W.A. \& Van Hinte, J.E. 2004a: Strontium $\left({ }^{87} \mathrm{Sr} /{ }^{86} \mathrm{Sr}\right)$ dating of marine shells from Pliocene and Pleistocene shallow marine deposits in the Netherlands. Netherlands Journal of Geosciences - Geologie en Mijnbouw 83, 41-48. https://doi.org/10.1017/S001677460002045X.

Jansen, H.S.M., Huizer, J., Dijkmans, J.W.A., Mesdag, C. \& Van Hinte, J.E. 2004b: The Geometry and stratigraphic position of the Maassluis Formation (western Netherlands and southeastern North Sea). Netherlands Journal of Geosciences - Geologie en Mijnbouw 83, 93-100.

https://doi.org/10.1017/S0016774600020060.

Kellogg, T.B. 1977: Paleoclimatology and Paleo-oceanography of the Norwegian and Greenland Seas: The last 450,000 years. Marine Micropalaeontology 2, 235-249. https://doi.org/10.1016/0377-8398(77)90013-5.

King, C. 1989: Cenozoic of the North Sea. In Jenkins, D.G. \& Murray, J.W. (eds.): Stratigraphical Atlas of Fossil Foraminifera, Ellis Horwood Ltd., Chichester, pp. 418-489. 
Kürschner, W.M. \& Herngreen, G.F.W. 2010: Triassic palynology of central and northwestern Europe: a rewiev of palynofloral diversity patterns and biostratigraphic subdivisions. Geological Society London, Special Publications 334, 263-283. https://doi.org/10.1144/SP334.11.

Larsen, H.C, Saunders, A.D., Clift, P.D., Begét, J., Wei, W., Spezzaferri, S., Ali, J., Cambray, H., Demant, A., Fitton, G., Fram, M.S., Fukuma, K., Gieskes, J., Holmes, M.A., Hunt, J., Lacasse, C., Larsen, L.M., Lykke-Andersen, H., Meltser, A., Morrison, M.L., Nemoto, N., Okay, N., Saito, S., Sinton, C., Stax, R., Vallier, T.L., Vandamme, D. \& Werner, R. (The ODP Leg 152 Scentific Party), 1994: Seven Million Years of Glaciation in Greenland. Science, New Series, Vol. 264, No. 5161, 952-955.

Lindner, L., Gozhik, P., Maraciniak, B., Marks, L. \& Yelovicheva, Y. 2004: Main climate changes in the Quaternary of Poland, Belarus and Ukraine. Geological Quaternary 48, 97-114.

Lund, J.J. 1977: Rhaetian to Lower Liassic palynology of the onshore south-eastern North Sea Basin. Danmarks Geologiske Undersøgelse II Række 109, 129pp.

Løseth, H. \& Henriksen, S. 2005: A Middle to Late Miocene compression phase along the Norwegian passive margin. In: Doré, A.G. \& Vining, B.A. (eds.): Petroleum Geology: North-West Europe and Global Perspectives-Proceedings of the 6th Petroleum Geology Conferance, 845-859.

https://doi.org/10.1144/0060845.

Løseth, H. \& Nygård, A. 2019: Controversies on ages of Quaternary sediments in the northern North Sea. NGF Abstract \& Proceedings, Number 1, 56-57.

Manum, S.B., Boulter, M.C., Gunnarsdottir, H., Rangnes, K. \& Scholze, A. 1989: 32. Eocene to Miocene palynology of the Norwegian Sea (ODP Leg 104). In: Eldholm, O. et al. (eds.): Proceedings of the Ocean Drilling Program, Scientific Results 104, 611-662. https://doi.org/10.2973/odp.proc.sr.104.176.1989.

Montelli, A., Dowdeswell, J.A., Ottesen, D. \& Johansen, S.E. 2017: Ice-sheet dynamics through the Quaternary on the mid-Norwegian continental margin inferred from 3D seismic data. Marine and Petroleum Geology 80, 228-242. https://doi.org/10.1016/j.marpetgeo.2016.12.002.

Newton, A.M.W. \& Huuse, M. 2017: Glacial geomorphology of the central Barents Sea: Implications for the dynamic deglaciation of the Barents Sea Ice Sheet. Marine Geology 387, 114-131.

https://doi.org/10.1016/j.margeo.2017.04.001.

Npd.no/facts (Norwegian Petroleum Directorate (NPD) Fact-pages).

https://factpages.npd.no/factpages/Default.aspx?culture=no.

Nygård, A., Sejrup, H.P., Haflidason, H. \& Bryn, P. 2005: The glacial North Sea Fan, southern Norwegian Margin: architecture and evolution from the upper continental slope to the deep-sea basin. Marine and Petroleum Geology 22, 71-84. https://doi.org/10.1016/B978-0-08-044694-3.50010-X.

Olesen, O., Gellein, J., Gernigon, L., Kihle, O., Koziel, J., Lauritsen, T., Mogaard, J. O., Myklebust, R., Skilbrei, J.R. \& Usov, S. 2010: Magnetic anomaly map, Norway and adjacent areas, scale 1:3 mill, Geological Surway of Norway.

Ottesen, D., Rise, L., Sletten Andersen, E., Bugge, T. \& Eidvin, T. 2009: Geological evolution of the Norwegian continental shelf between $61^{\circ} \mathrm{N}$ and $68^{\circ} \mathrm{N}$ during the last 3 million years. Norwegian Journal of Geology 89, 251-265.

Ottesen, D., Dowdeswell, J.A. \& Bugge, T. 2014: Morphology, sedimentary infill and depositional environments of the Early Quaternary North Sea Basin $\left(56^{\circ}-62^{\circ} \mathrm{N}\right)$. Marine and Petroleum Geology 56, 123-146. https://doi.org/10.1016/j.marpetgeo.2014.04.007.

Ottesen, D., Batchelor, C.L., Dowdeswell, J.A. \& Løseth, H. 2018: Morphology and pattern of Quaternary sedimentation in the North Sea Basin (52-62 N). Marine and Petroleum Geology 98, 836-859.

https://doi.org/10.1016/j.marpetgeo.2018.08.022. 
Reinardy, B.T.I., Hjelstuen, B.O., Sejrup, H.P. \& Augedal, H. 2017a: Late Pliocene-Pleistocene environments and glacial history of the northern North Sea. Quaternary Science Reviews 158, 107-126. https://doi.org/10.1016/j.quascirev.2016.12.022.

Reinardy, B.T.I., Sejrup, H.P., Hjelstuen, B.O., King, E. \& Augedal, H. 2017b: A Quaternary aminostratigraphy constraining chronology of depositional environments in the North Sea Basin. Marine Geology 402, 139-152. https://doi.org/10.1016/j.margeo.2017.11.004.

Riding, J.B. \& Thomas, J.E. 1992: Dinoflagellate cysts of the Jurassic System. In: Powell, A. J. (ed.): A stratigraphic index of dinoflagellate cysts, British Micropalaeontological Society Publication Series, London, Chapman \& Hall, pp. 7-97. https://doi.org/10.1007/978-94-011-2386-0_2.

Riis, F. \& Wolff, A. 2020: Use of pore pressure data from the Norwegian Continental Shelf to characterize fluid-flow processes in geological timescales. In: Chiarella, D., Archer, S.G., Howell, J.A., Jackson, C.A.-L., Kombrink, H. \& Partruno, S. (eds.): Cross-Border Themes in Petroleum Geology II: Atlantic Margin and Barents Sea. Geological Society, London, Special Publications, 495.

Rise, L., Ottesen, D., Berg, K. \& Lundin, E. 2005: Large-scale development of the mid-Norwegian margin during the last 3 million years. Marine and Petroleum Geology 22, 33-44. https://doi.org/10.1016/B978-0-08-044694-3.50007-X.

Rodriguez-Tovar, F.J. \& Hernandez-Molina, F.J. 2018: Ichnological analysis of contourites: Past, present and future. Earth-Science Reviews 182, 28-41. https://doi.org/10.1016/j.earscirev.2018.05.008.

Schiøler, P. 2005: Dinoflagellate cysts and acritarchs from the Oligocene - Lower Miocene interval of the Alma-1x well, Danish North Sea. Journal of Micropalaeontology 24, 1-37.

https://doi.org/10.1144/jm.24.1.1

Schiøler, P., Andsbjerg, J., Clausen, O.R., Dam, G., Dybkjær, K., Hamberg, L., Heilmann-Clausen, C., Johannessen, E.P., Kristensen, L.E., Prince, I. \& Rasmussen, J.A. 2007: Lithostratigraphy of the Palaeogene - Lower Neogene succession of the Danish North Sea. Geological Survey of Denmark and Greenland Bulletin 12. https://doi.org/10.34194/geusb.v12.5249.

Sejrup, H.P., Aarseth, I., Haflidason, H., Løvlie, R., Bratten, Å., Tjøstheim, G., Forsberg, C.F. \& Ellingsen, K.L. 1995: Quaternary of the Norwegian Channel; paleoceanography and glaciation history. Norsk Geologisk Tidsskrift 75, 65-87.

Skarbø, O. \& Verdenius, J.G. 1986: Catalogue of microfossils, Quaternary - Tertiary. IKU Publication 113.

Sliwinska, K.K., Abrahamsen, N., Beyer, C., Brünings-Hansen, T., Thomsen, E., Ulleberg, K. \& HeilmannClausen, C. 2012: Bio- and magnetostratigraphy of Rupelian-mid Chattian deposits from the Danish land area. Review of Palaeobotany and Palynology 172, 48-69. https://doi.org/10.1016/j. revpalbo.2012.01.008.

Spiegler, D. \& Jansen, E. 1989: Planktonic Foraminifer Biostratigraphy of Norwegian Sea Sediments: ODP Leg 104. In: Eldholm, O., Thiede, J., Tayler, E. et al. (eds.): Proceedings of the Ocean Drilling Program, Scientific Results 104: College Station, TX (Ocean Drilling Program), pp. 681-696. https://doi.org/10.2973/odp.proc.sr.104.157.1989.

Stow, D.A.V. \& Faugeres, J.C. 2008: Contourite facies and the facies model. In: Rebesco, M. \& Camerlenghi, A. (eds.): Contourites, Developments in sedimentology 60, pp. 223-256.

https://doi.org/10.1016/S0070-4571(08)10013-9.

Traverse, A. 2007: Paleopalynology. Springer Verlag, The Netherlands. https://doi.org/10.1007/978-1-4020-5610-9.

Weaver, P.P.E. 1987: Late Miocene to Recent planktonic foraminifers from the North Atlantic: Deep Sea Drilling Project Leg 94. Initial Reports of the Deep Sea Drilling Project 94, 703-727.

https://doi.org/10.2973/dsdp.proc.94.114.1987. 
Weaver, P.P.E. \& Clement, B. M. 1986: Synchronicity of Pliocene planktonic foraminiferid datums in the North Atlantic. Marine Micropalaeontology 10, 295-307.

https://doi.org/10.1016/0377-8398(86)90033-2.

Wesselingh, F.P., Meijer, T., \& Cleveringa, P. 2005: Comments on "The geometry and stratigraphic position of the Maassluis Formation (western Netherlands and south-eastern North Sea" by Jansen et al. (2004b). Netherlands Journal of Geosciences - Geologie en Mijnbouw 84, 51-52.

https://doi.org/10.1017/S0016774600022903.

Zagwijn, W.H. 1985: An outline of the Quaternary stratigraphy of the Netherlands. Geologie en Mijnbouw 64, 251-272.

Zagwijn, W.H. 1989: The Netherlands during the Tertiary and the Quaternary: a case history of coastal lowland evolution. Geologie en Mijnbouw 68, 107-120. https://doi.org/10.1007/978-94-017-1064-0_6. 